\title{
The Rose "Ophelia" and Flower Symbolism in "Hamlet"
}

\author{
Turchynova Ganna
}

Candidate of Pedagogic Sciences, Associate Professor

Dragomanov National Pedagogical University

Pet'ko Lyudmila

Candidate of Pedagogic Sciences, Associate Professor

Dragomanov National Pedagogical University

Novak Tatiana

Student of Faculty of Natural and Geographical Education and Ecology

Dragomanov National Pedagogical University

\section{...we know what we are, but know not what we may be William Shakespeare, Hamlet}

\begin{abstract}
The study examines some topical issues associated with the quality of vocational training of future biologists. The article demonstrates the need for and the objective nature of transformation of the linguistic and educational paradigm from communicative to intercultural.

The authors emphasize that it is important in the process of teaching foreign language biology students to create such professionally oriented foreign language learning environment that would form professional and sociocultural competences in students. The authors propose a nonstandard approach to the formation of professional competence in future biologists: learning the biological characteristics of the rose "Ophelia" by studying Shakespeare's tragedy "Hamlet" in the context of Ophelia's image. Ophelia is the symbol of femininity. Her lines and the lines addressed to her show a lot about both her character and Shakespeare's views of femininity. Considering the importance of professional and speech culture, special attention is also paid to professional-focused technology in intercultural communication teaching.

The symbolism of the flowers of Ophelia's "bouquet" is describedж the image of Ophelia in films, music, ballets, paintings is presented.

Key words: future biologists, foreign language, professional competence, socio-cultural competence, rose "Ophelia", breeder William Paul, Shakespeare, symbolism of flowers.

The dead do not sleep in Denmark. Thrice the vision of the suddenly departed king has haunted the night watchmen. Upon seeing his own son, prince Hamlet, the ghost calls him away to divulge most nefarious secret. This most noble king was murdered by his own brother, Hamlet's uncle, who now wears his crown and beds his bride. To the prince he charges with the unholy quest to avenge his death and kill his murderer. Young Hamlet, shocked and amazed, swears to do the bloody deed.
\end{abstract}


Thus begins one of the greatest works by the greatest English author - William Shakespeare [23] (Audiobook) [60, p. 28-31] (Fig. 1, 2, 3.).

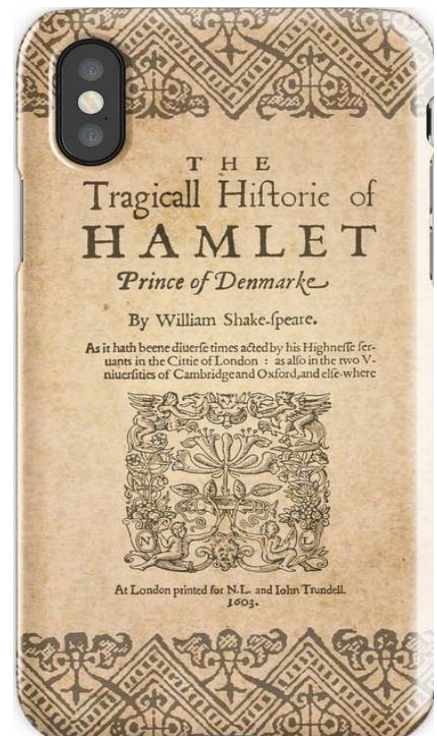

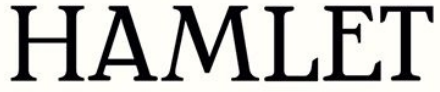

WILLIAM SHAKESPEARE

To be, or not to be: that is the question: Whether 'tis nobler in the mind to suffer The slings and arrows of outrageous fortune, Or to take arms against a sea of troubles, And by opposing end them? To die: to sleep; No more; and, by a sleep to say we end The heart-ache and the thousand natural shocks That flesh is heir to, 'tis a consummation Devoutly to he wish'd To die to sleen.

Fig. 1. Shakespeare, Hamlet, 1603. Fig. 2. Hamlet's soliloquy.

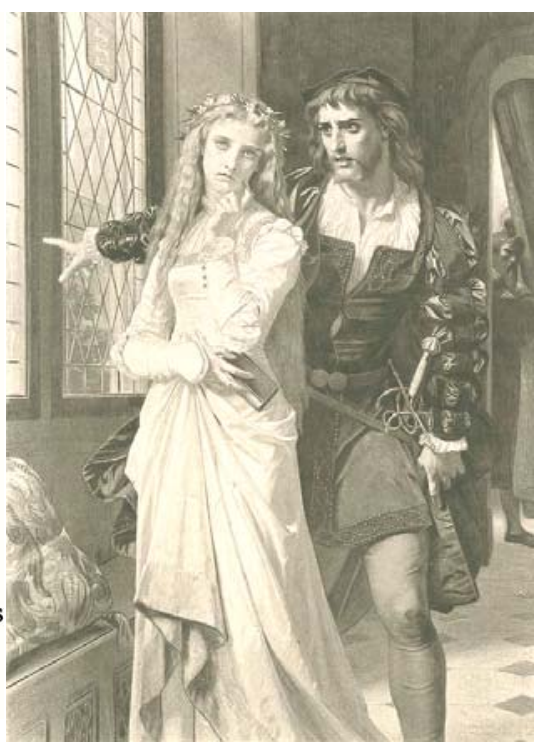

Fig. 3. Ophelia and Hamlet by Eugène Delacroix

The soliloquy is essentially all about life and death: "To be or not to be" means "To live or not to live" (or "To live or to die"). Hamlet discusses how painful and miserable human life is, and how death (specifically suicide) would be preferable, would it not be for the fearful uncertainty of what comes after death.

But Ophelia, Hamlet's beloved wife-to-be, is the symbol of femininity in the lengthy play. Her lines and the lines addressed to her show a lot about both her character and Shakespeare's views of femininity [10] (Fig. 3, 6).

Below is a portrait "Shakespeare's Flowers" (1835) (Fig. 4). This work, painted

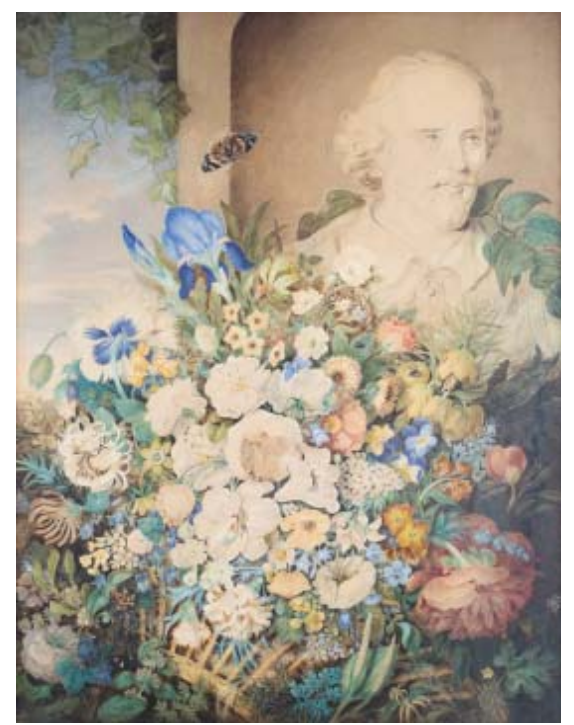

Fig. 4. Shakespeare's Flowers (1835) [2].

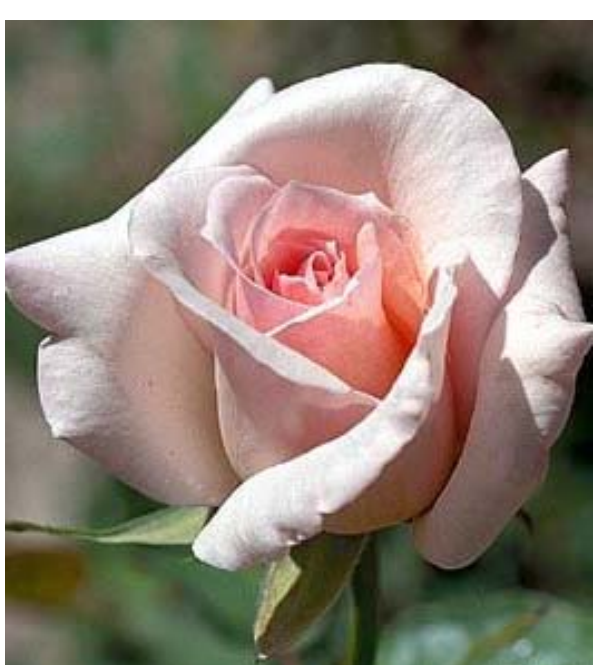

Fig. 5. The Rose Ophelia.

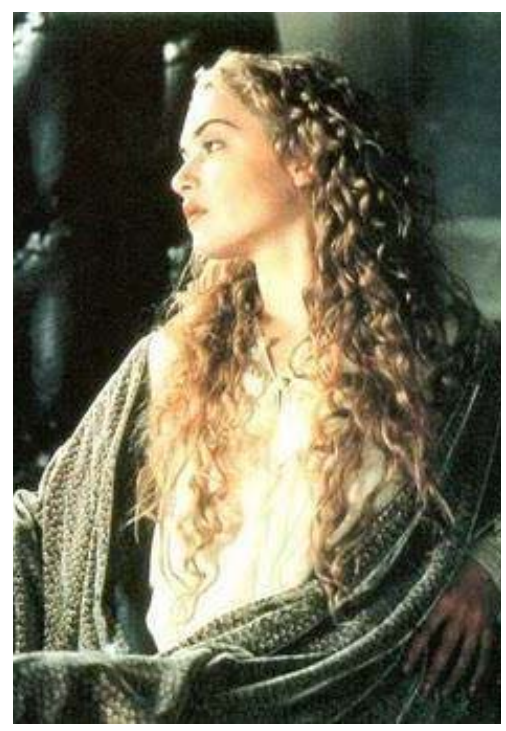

Fig. 6. Kate Winslete as Ophelia (1996). 
by the artist Clara Maria Pope (1767-1838), is one that most commonly catches the eye of visitors during tours of Private Apartments in Sir John Soane's Museum (London). An 1837 inventory of the Soane describes it as 'The Bust of Shakespeare encircled by all the Flowers mentioned in his Works' [59].

Hamlet is a long play full of essential characters and important lines. One of the main characters is Ophelia, Hamlet's beloved. Ophelia has only 178 lines in the play.

When Hamlet accidentally kills Ophelia's father, and she becomes mad, Gertrude tries to calm her [10].

Ophelia is a passive character, mainly silent, that wants to be active. She breaks her silence when madness strikes her, and her words reveal a lot about the play.

Act 1 , scene 3 , is Ophelia's first scene (see video [18; 20]). She asks two short

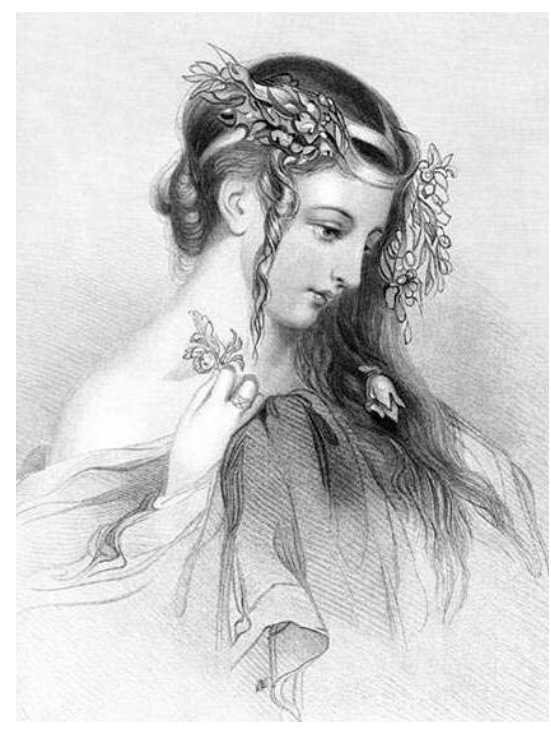

Fig. 7. "Ophelia" by Hayter John (1850).

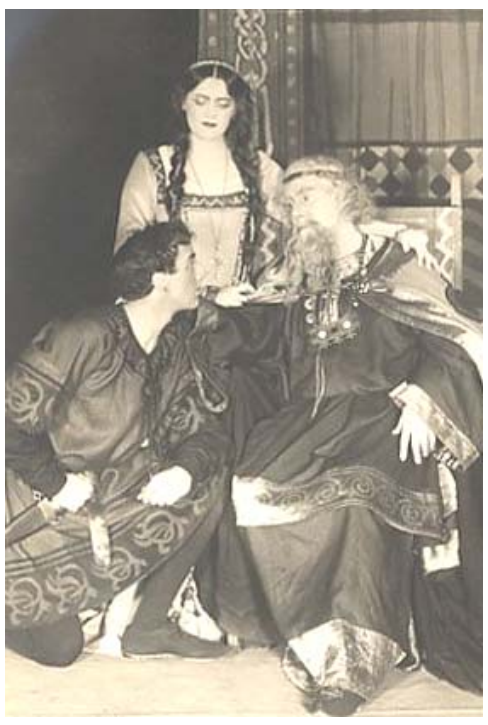

Fig. 8. Act 1 Scene 3. Laertes,

Polonius and Ophelia.

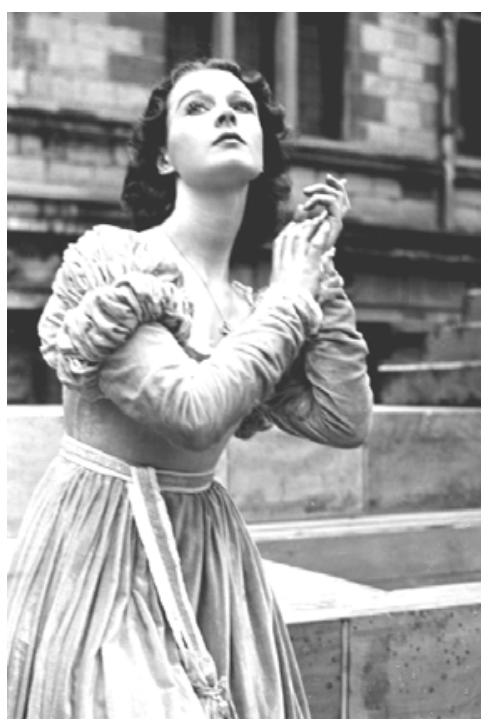

Fig. 9. Vivien Leigh as Ophelia

(1937) questions in the middle of her brother's lines, trying to convince her not to believe Hamlet's love, and her father's, trying to tell her what to think. The conversation goes on until she says, "I do not know, my lord, what I should think." Polonius replies to her, "Marry, I will teach you," after telling her that she should not believe Hamlet's love like a "green girl." This scene sums up how Ophelia is always treated by men of her life and how she obeys as a daughter. Like Juliet, Ophelia cannot find a way out of the prison her world has become [10].

When she agrees to help Claudius and Polonius find out why Hamlet pretends to be mad, she chooses the side of her father against her beloved. When Hamlet asks 
her where her father is, and she answers "at home," he finds out that Ophelia is betraying him. They both know that her father is hiding behind the curtain.

Hamlet is disappointed by the women around him: his mother has married the murderer of his father, and his beloved is conspiring against him. He says to Ophelia, "get thee to a nunnery" to escape her slanderous reputation and live a chaste life [10], see video [15].

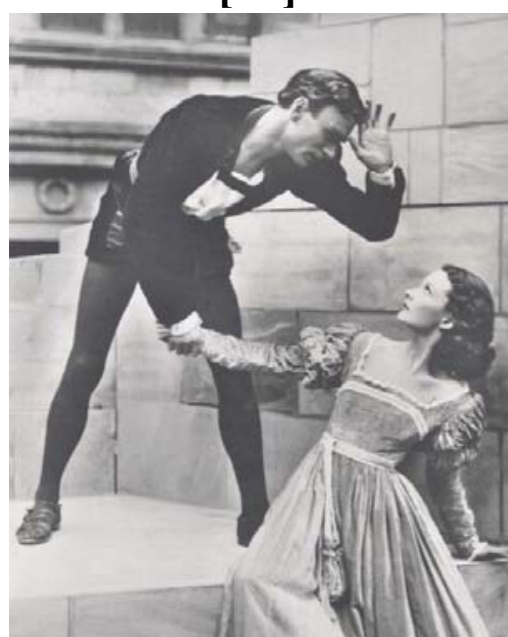

Fig. 11. Oliver Laurence as Hamlet Vivien Leigh as Ophelia (1937).

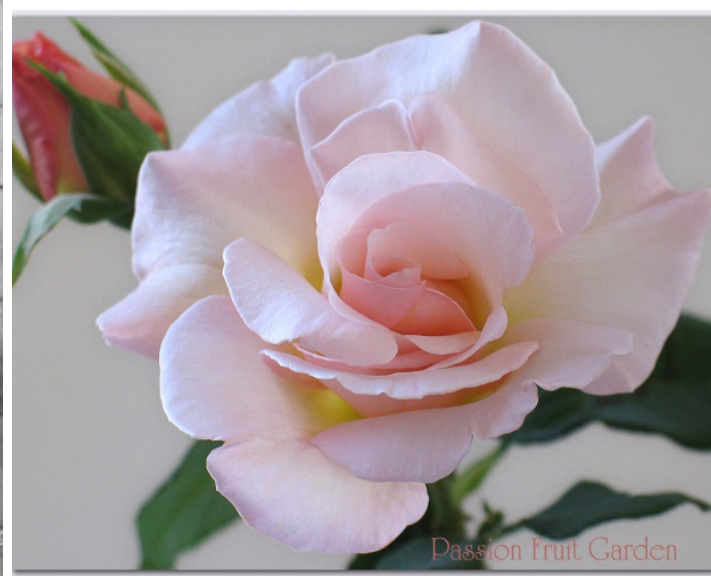

Fig. 10. The Rose Ophelia

Ophelia is a difficult role to play because her character, like Gertrude's, is murky. Part of the difficulty is that Shakespeare wrote his female roles for men, and there were always limitations on them that restricted and defined the characterizations

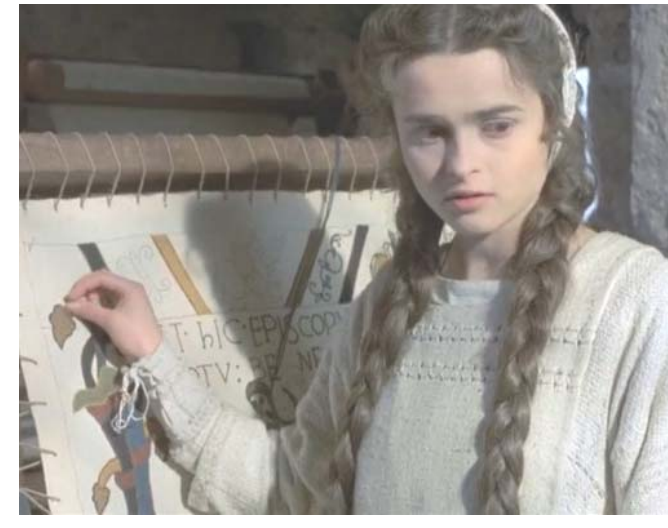

Fig. 13. Helena Bonham Carter as Ophelia (1990).

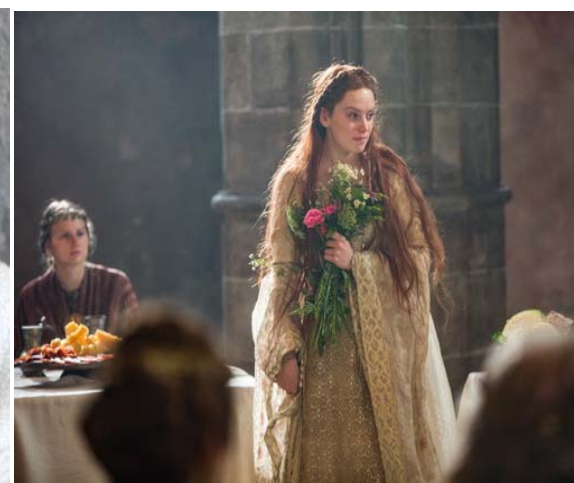

Fig. 14. Daisy Ridley

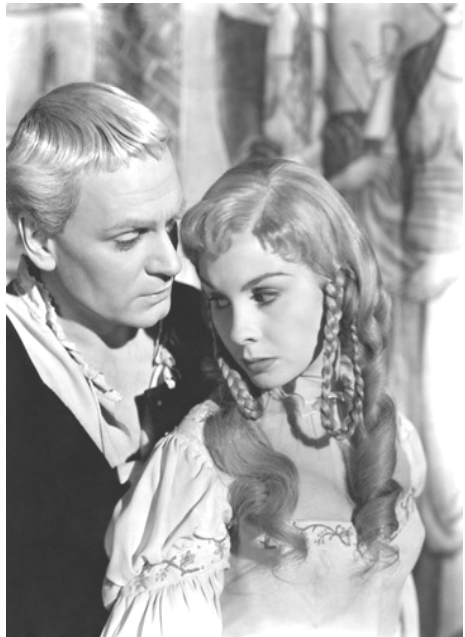

Fig. 12. Jean Simmons as Ophelia (1948).

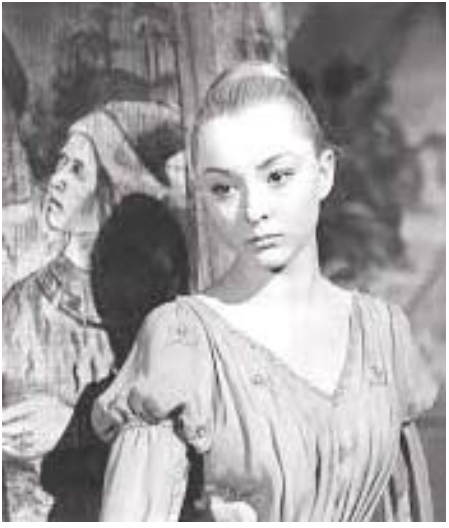

as Ophelia (2018). Fig. 15. Anastasiya Vertinskaya as Ophelia (1964). devised. In the case of an ingenue like Ophelia, a very young and lovely woman, Shakespeare would have been writing for a boy. The extent to which a boy could grasp subtle nuances might have prevented the playwright from fleshing out the character more fully [7], see movie [78; 79; 21].

Ophelia is torn between two contradictory poles. Her father and brother believe 
that Hamlet would use her, that he would take her virginity and throw it away because she could never be his wife. Her heart has convinced her that Hamlet loved her, though he swears he never did (see videos $[15 ; 19 ; 20]$ ). To her father and brother, Ophelia is the eternal virgin, the vessel of morality whose purpose is to be a dutiful wife and steadfast mother. To Hamlet, she is a sexual object, a corrupt and deceitful lover. With no mother to guide her, she has no way of deciphering the contradictory expectations [7].

In Act 4, following the death of Polonius, his daughter Ophelia goes mad. Spurned by her lover Hamlet, who himself seems to have lost his mind, and left alone in a castle with no one to trust, Ophelia loses her grip on reality (see videos [30; 38; 69], Fig. 14, 16). As she prances through the halls of Elsinore singing songs that range from childish to bawdy to macabre, she passes out invisible "flowers" to those she meets, the eclectic variety of which symbolize her own complex personality. She passes out rosemary (traditionally carried by mourners at funerals (Fig. 18), pansies (whose name is derived from the French word pensie, meaning "thought" or "remembrance" (Fig. 19), fennel (a quick-dying flower symbolizing sorrow (Fig. 20),

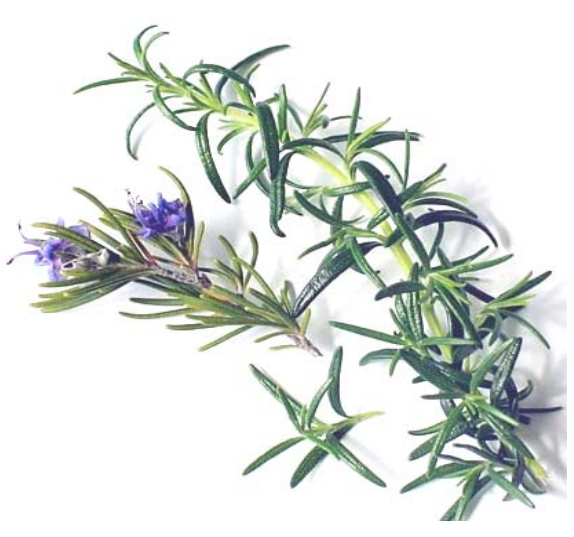

Fig. 18. Rosemary.

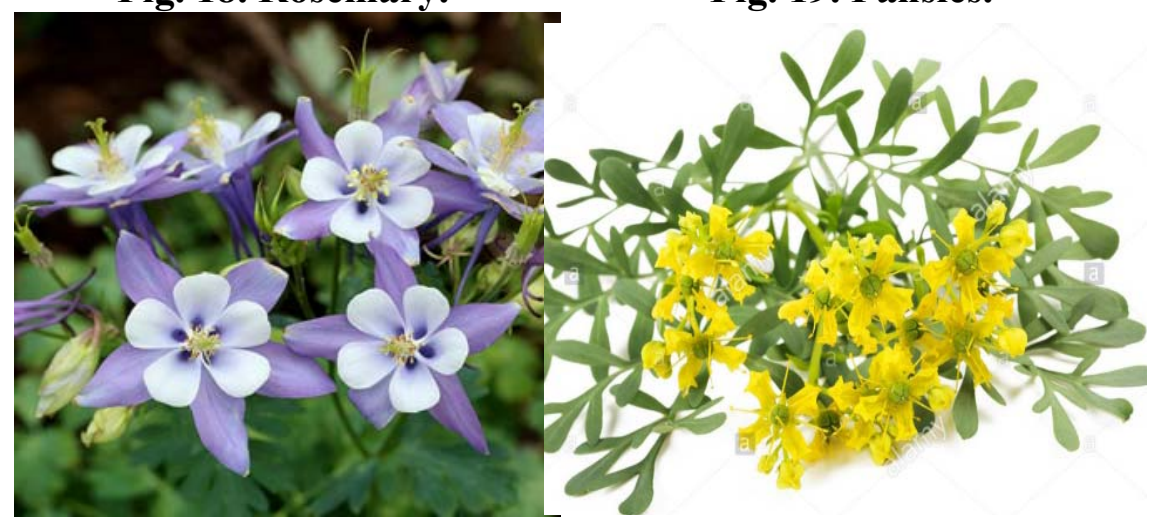

Fig. 21. The Columbines.

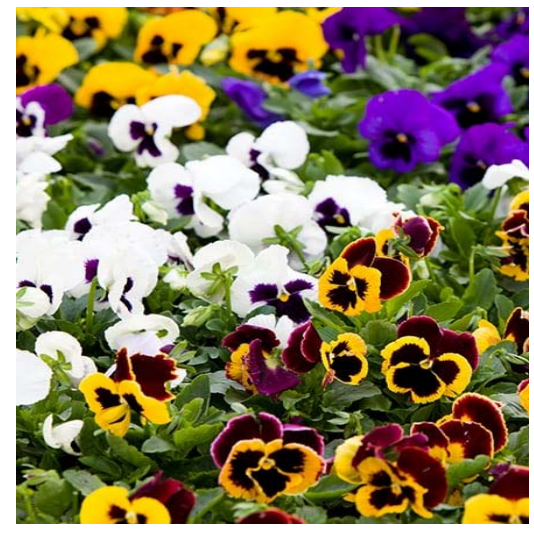

Fig. 19. Pansies.

Fig. 22. Rue.

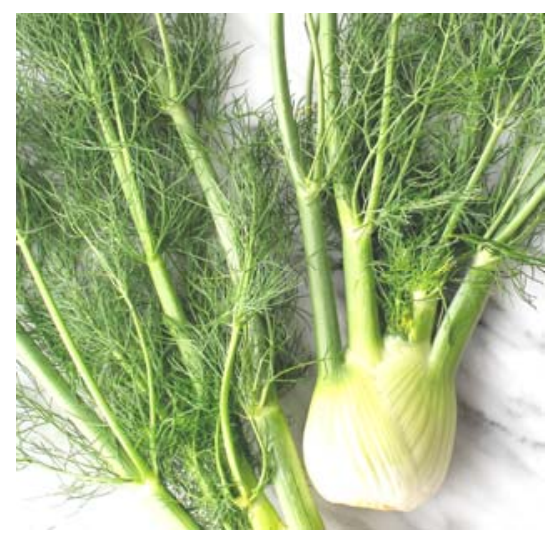

Fig. 20. Fennel-bulb.

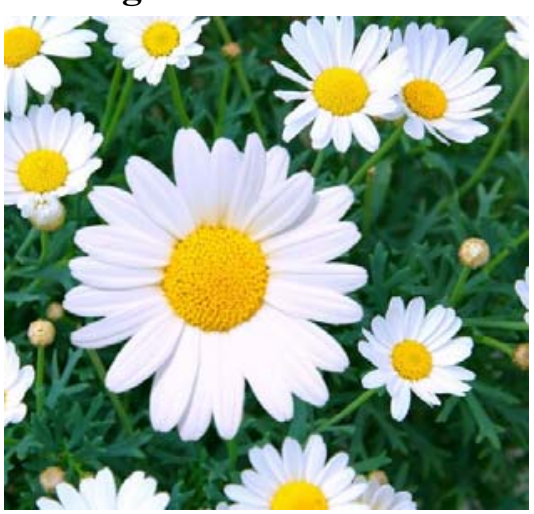

Fig. 23. Daisies. 
columbines (a flower symbolizing affection, often given to lovers (Fig. 21), and daisies (symbols of innocence and purity, and the flower of the Norse fertility goddess Freya, Fig. 23). But Ophelia states that she has no violets left - they all withered when her father died.

Violets are symbols of modesty (Fig. 24), often tied to the Virgin Mary, implying that Ophelia no longer cares about upholding shallow social norms in the wake of such a devastating tragedy (see video $[16 ; 39]$ ).
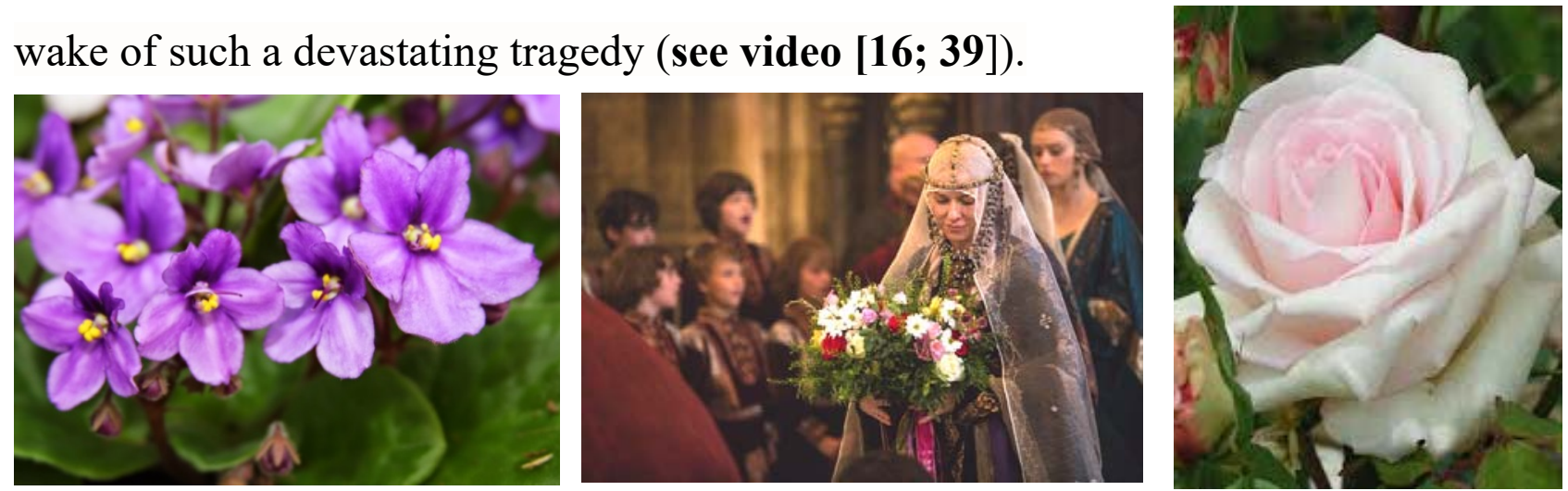

Fig. 24. Violets.

Fig. 25. Ophelia's "bouquet" (Hamlet, 2018). Fig. 26. The Rose "Ophelia".

Ophelia's "bouquet" is contradictory: there are flowers associated with sorrow and mourning, but also happy remembrances; there are flowers that denote purity and chastity alongside flowers given as tokens of sexual or romantic love between partners [35], Fig. 25, 27.

\section{OPHELIA}

There's rosemary, that's for remembrance; pray,

love, remember: and there is pansies. that's for thoughts.

\section{LAERTES}

A document in madness, thoughts and remembrance fitted.

\section{OPHELIA}

There's fennel for you, and columbines: there's rue for you; and here's some for me: we may call it herb-grace o' Sundays: O you must wear your rue with a difference. There's a daisy: I would give you some violets, but they withered all when my father died: they say he made a good end... (Sings) [60, p. 106-107]. Fig. 27. "Ophelia" by William Paget.

There are two interpretations of Ophelia's lines in Hamlet. First is that Ophelia chooses plants and flowers that symbolise her doomed romance with Hamlet. The Columbine (Fig. 21) for example being symbolic of ingratitude and forsaken love and the Fennel being symbolic of Hamlet's shallow and false love. However many historians and critics have noted that Hamlet does not appear in this scene. Instead Ophelia hands out her flowers to the court in front of the King and Queen. It is 
therefore more likely that Ophelia's message, shrouded in her apparent madness, is aimed at the King and his court. Below given a few suggestions as to what Ophelia is really saying when she hands out her flowers [36].

Rosemary is for remembrance (Fig. 18). Ophelia's plea to the court to remember has a touch of melancholy about it. As Rosemary formed part of burial wreaths it serves as a forewarning to her tragic death.

Rosemary and Rue, herbs that on two occasions Shakespeare placed near to one another.

For you there's rosemary and rue ...

Grace and remembrance be to you both

The Winter's Tale, Act IV, Scene 3

There's rosemary, that's for remembrance; pray you love, remember ... there's rue for you, and here's some for me: we may call it herb-grace o' Sundays:

$\mathrm{O}$, you must wear your rue with a difference

Hamlet, Act IV, Scene 5 [36].

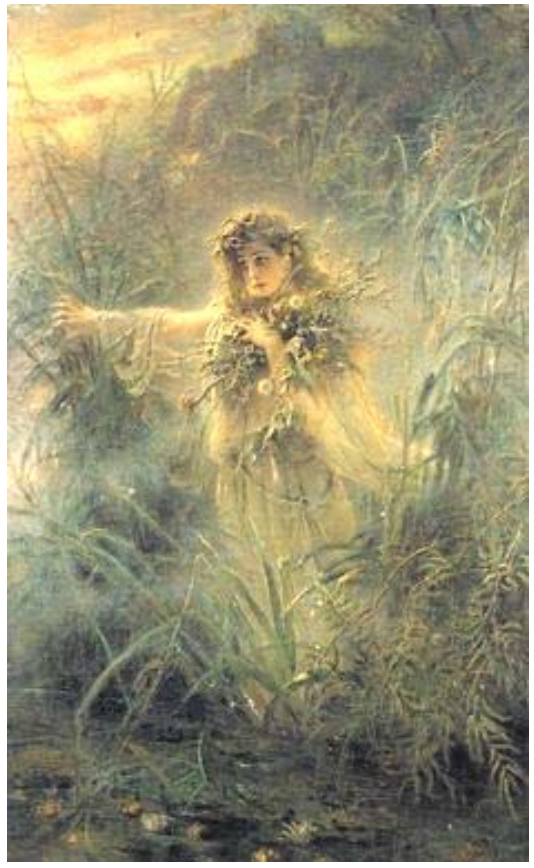

Fig. 28. "Ophelia" by K. E. Makovsky.

Rosemary (Rosmarinus officinalus) has been associated with remembrance since ancient Greece where students would wear garlands of rosemary whilst studying to aid their memories. Its botanical name comes from the Latin meaning "dew of the sea", a reference to its blue flowers and its original habitat on the coasts of the Mediterranean. In Shakespeare's day it was highly valued and had a variety of uses. It was used in cooking, in floor strewings, it was distilled to make medicinal simples and when grown tall its stems were used to make lutes [53].

As an evergreen Rosemary represented both remembrance and constancy and played a part in both Elizabethan weddings and funerals. The 17th century poet Robert Herrick wrote "Grow it for two ends, it matters not at all, Be it for my bridal or burial." At weddings Rosemary was carried by the bridesmaids and sprigs of it were strewn on the ground. As a symbol of fidelity the Nurse in Romeo and Juliet remarks:

Doth not rosemary and Romeo begin both with a letter? Romeo and Juliet, Act II, Scene 4

There was an old folk belief that if a man could not smell Rosemary he was incapable of loving a woman. 
Rosemary also formed part of burial wreaths, which later appear when Juliet is thought to have died.

Dry up your tears, and stick your rosemary

On this fair corse.

Romeo and Juliet, Act IV, Scene 5

No doubt another reason for Shakespeare using it earlier in the play was to foreshadow the future tragic events [53].

Sir Thomas Moore wrote: "As for Rosemarie I let it run alle over my garden walls, not onlie because my bees love it, but because tis the herb scared to remembrance and therefore to friendship, whence a sprig of it hath a dumb language that Maketh it the chosen emblem at our funeral wakes and in our burial grounds" [53].

Rosmarinus officinalus (Fig. 18, 29)

Family Lamiaceae.

Type: Perennial Evergreen.

Flowers: pink, white, blue, or purple.

Height: 1 to 6 feet.

Flowering: Summer. It lives more than 2 years [14], see video [17].

Fig. 29. Rosmarinus officinalus.

\section{Rue (Ruta graveolens) (Fig. 30)}

Here did she fall a tear; here in this place, I'll set a bank of rue, sour herb of grace;

Rue, even for ruth here shortly shall be seen

In the remembrance of a weeping queen. Richard II, Act III, Scene 4

Rue has a strong aromatic smell and a bitter taste. The first part of its botanical name comes

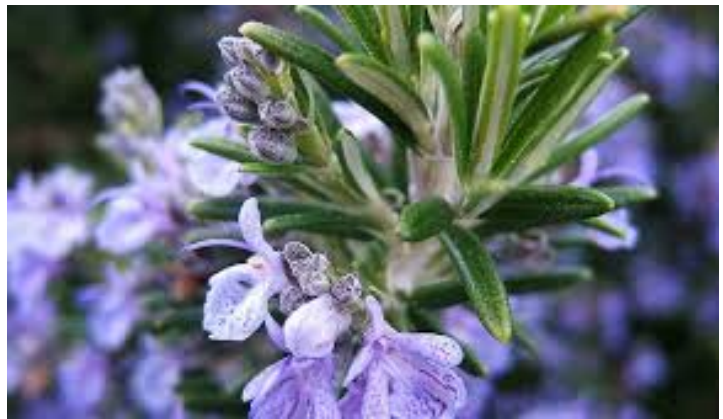

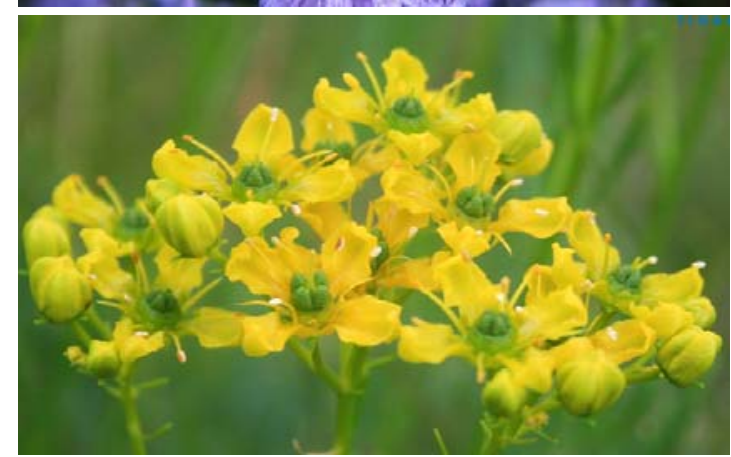

Fig. 30. Ruta graveolens. from the Greek reuo, meaning to set free. In ancient times it was thought to be an antidote for poison and disease, in Elizabethan England it was carried around as protection against the plague and witchcraft and was used in herbal strewings to repel insects. Due to its bitter taste the plant has long been symbolic of sorrow, regret and repentance, hence the expression "you'll rue the day" meaning "you'll be sorry for this." When Ophelia hands it to Queen Gertrude in Hamlet, it is a subtle rebuke of her faithlessness [53].

Another name for the plant was Herb of Grace or Herb Grace o' Sundays as it 
was used in the early Catholic Church to sprinkle holy water and to wash away sins. The word ruth comes from the word rue and more usually meant to feel pity for or to grieve.

In large doses Rue is toxic and is not generally recommended for internal use. It may also be dangerous to grow in your garden if you have pets. In medieval times it was sometimes used to hasten labour or in extreme cases as an abortifacient. This has led to speculation that when Ophelia utters the lines "there's rue for you, and here's some for me", she is confessing to an unwanted pregnancy, revealing another reason for ending her life [53].

\section{Rue Scientific Classification (Fig. 30)}

Kingdom: Plantae (Plantes, Planta, Vegetal, plants).

Subkingdom: Viridiplantae (Green plants).

Infrakingdom: Streptophyta (Land plants).

Superdivision: Embryophyta.

Division: Tracheophyta (Vascular plants, tracheophytes).

Class: Magnoliopsida.

Order: Sapindales.

Family: Rutaceae (Rues, rutacées).

Genus: Ruta L. (Rue).

Species: Ruta graveolens L. (Common rue).

Native: Mediterranean region and Canary islands.

Plant Growth: Glabrous, woody-based, shrubby.

Habit: perennial.

Soil: Well-drained.

Plant Size: 2 to $21 / 2$ feet in height.

Leaf: Pinnately divided, 3-5 inches long.

Fruit shape \& size: Capsule.

Fruit color: Grayish-brown.

Aroma: Strong, heavy and unpleasant.

Taste: Intense bitter.

Seed: Ovoid [95].

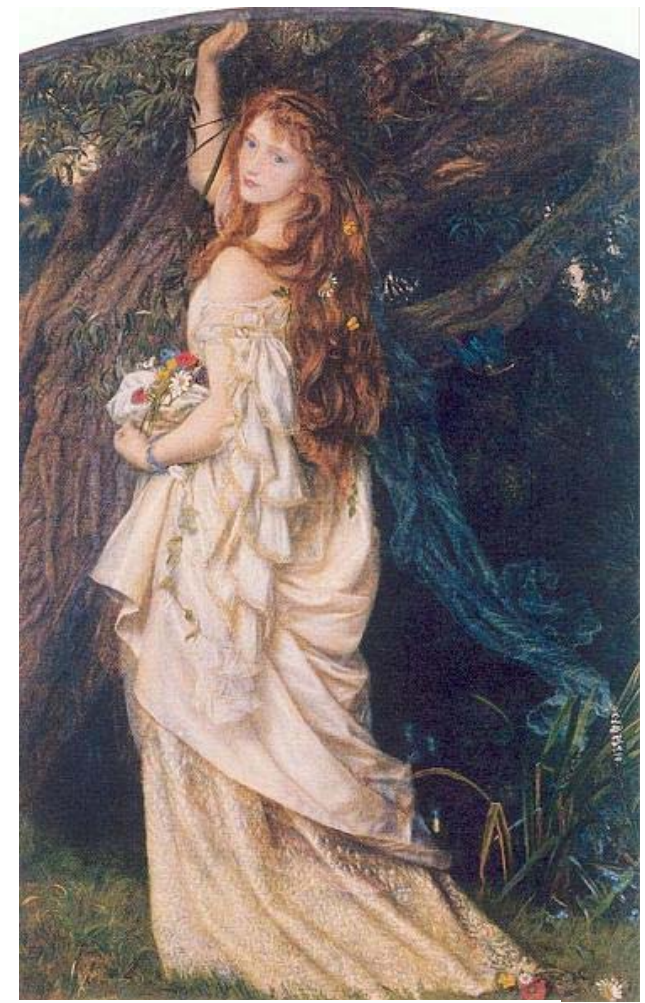

Fig. 31. Ophelia (1863-1864) by Arthur Hughes.

The Daisy (Fig. 23) and Pansy (Fig. 19, 32) are two flowers that are associated with Ophelia in Hamlet. We can learn more about their meaning and symbolism and other places where Shakespeare used them in his work [11].

$\ldots$ and there is pansies, that's for thoughts

Hamlet, Act IV, Scene 5

Pansy (Viola tricolor). The word pansy comes from the French pensée, meaning for thoughts. Other names for the flower include Johnny-Jump-Ups, ThreeFaces-Under-a-Hood, Herb-Trinity, Love-in-Idleness and Heartsease (Fig. 32). 
Herb-Trinity and its botanical name tricolor refers to the flowers' three main colours, white, purple and yellow. The flower was also an ingredient used in medieval love potions, hence the name Love-in-Indleness meaning love in vain. It's heart shaped petals were also thought to help heal a broken heart, so it was also known as Heartease. It is an extract of this flower that Oberon and Puck in A Midsummer Night's Dream, squeeze into the sleeping eyes of Titania, making her fall in love with the weaver Bottom. It is also later used on the youths in the enchanted forest.

"Yet mark'd I where the bolt of Cupid fell:

It fell upon a little western flower,

Before milk-white, now purple with love's wound, And maidens call it Love-in-Idleness ...

The juice of it on sleeping eyelids laid, Will make man or woman madly dote Upon the next live creature that it sees." A Midsummer Night's Dream, Act II, Scene 2 [11].

\section{Viola tricolor Scientific Classification}

Genus: Viola.

Species: tricolor.

Family: Violaceae.

Uses (Ethnobotany): Traditional medicines and dyes.

Life Cycle: Annual Perennial.

Country Or Region Of Origin: Europe and Asia.

Distribution: North America.

Dimensions: Height: $0 \mathrm{ft} .3$ in. $-0 \mathrm{ft} .10 \mathrm{in}$.

Width: $0 \mathrm{ft} .3$ in. $-1 \mathrm{ft} .0$ in.

Leaf Color: Green.

Leaf Type: Simple.

Stem: Green, straight, hairless, sometimes downy and is branched.

Fruit Type: Capsule.

Flower Color: Blue, cream/tan, gold/yellow, orange, purple/lavender, variegated, white.

Flower Inflorescence: Head.

Flower Value To Gardener: Edible, fragrant, showy.

Flower Bloom Time: Spring, summer.

Flower Petals: 4-5 petals/rays.

Flower Size: $<1$ inch.

Landscape Location: Meadow, naturalized area, pond, woodland.

Design Feature: Mass Planting [4], see video [28].

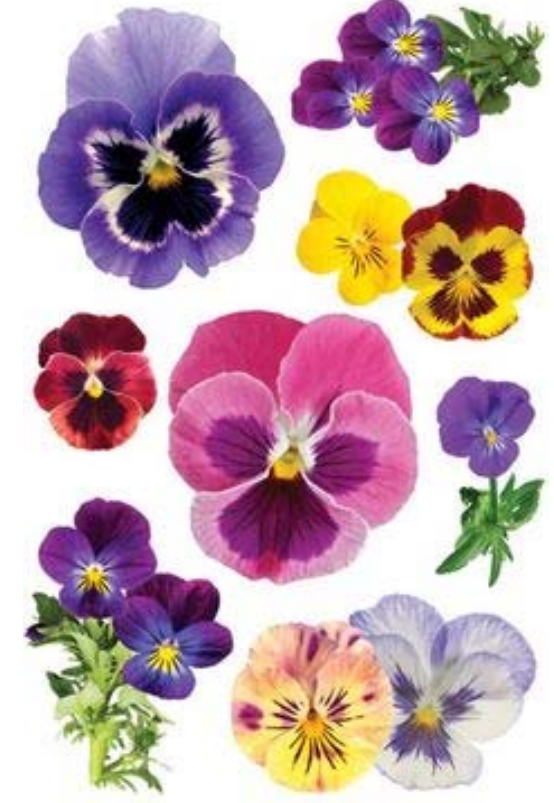

Fig. 32. Viola tricolor.

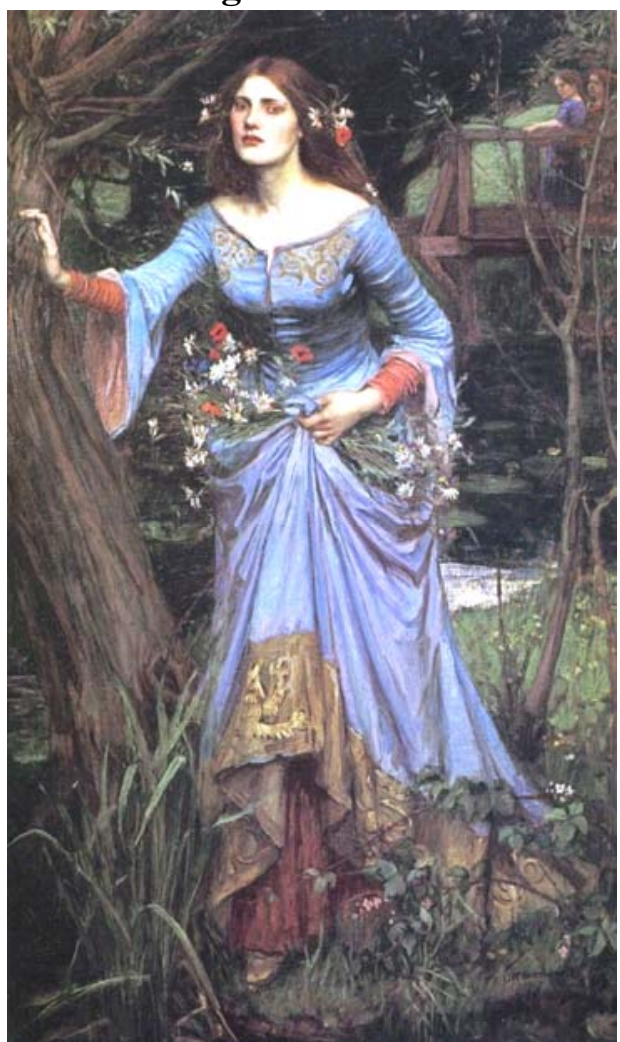

Fig. 33. "Ophelia" $(1910)[12,29]$ by John William Waterhouse (1849-1917). 
Daisy (Bellis perennis). The Daisy's botanical name comes from the Latin bellis, meaning pretty. Its English name is derived from the Anglo Saxon daeges eage or day's eye. It was so called because its petals open during the day and close at night. In Medieval times, Bellis perennis or the English Daisy was commonly known as "Mary's Rose" The Daisy (Fig. 23, 34) is often associated with childhood and innocence, in the north of England and in Scotland it is sometimes referred to as Bairnwort, bairn being another word for child. When Ophelia hands out her flowers to the court she announces the Daisy but does not hand it out, suggesting that there is no innocence or purity within the court.

Daisies continue to thrive in the English fields, lawns and grassy slopes and making daisy chains is still a common practice among children [11].

There's a daisy"

Hamlet, Act IV, Scene 5

There were fantastic garlands did she come,

Of crow-flowers, nettles, daisies and long purples.

Hamlet, Act IV, Scene7

When daisies pied, and violets blue,

And lady-smocks all silver white,

And cuckoo-buds of yellow hue,

Do paint the meadows with delight."

Love's Labour's Lost, Act V, Scene 2

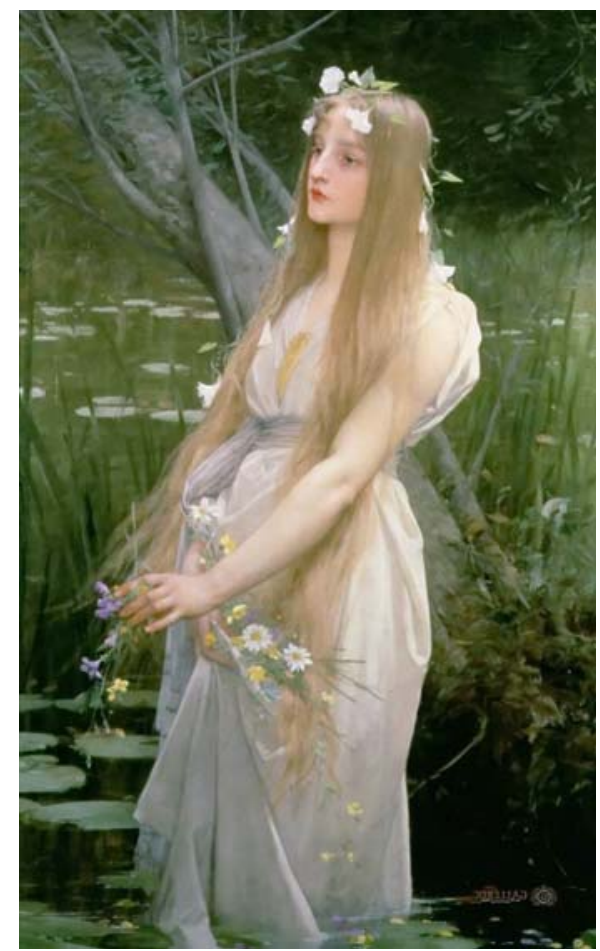

Fig. 34. "Ophelia" (1890)

by Jules-Joseph Lefebvre [29].

Kingdom: Plantae.

\section{Daisy (Bellis perennis) Scientific Classification}

Clade: Tracheophytes.

Clade: Angiosperms.

Clade: Eudicots.

Clade: Asterids.

Order: Asterales.

Family: Asteraceae [4].

Genus: Bellis (Fig. 35, 36).

Species: B. Perennis.

Common Name: English daisy.

Type: Herbaceous perennial.

Native Range: Northern Africa, Western Asia, Europe.

Zone: 4 to 8 .

Height: 0.25 to 0.50 feet.

Spread: 0.25 to 0.75 feet.

Fig. 35. Bellis perennis.

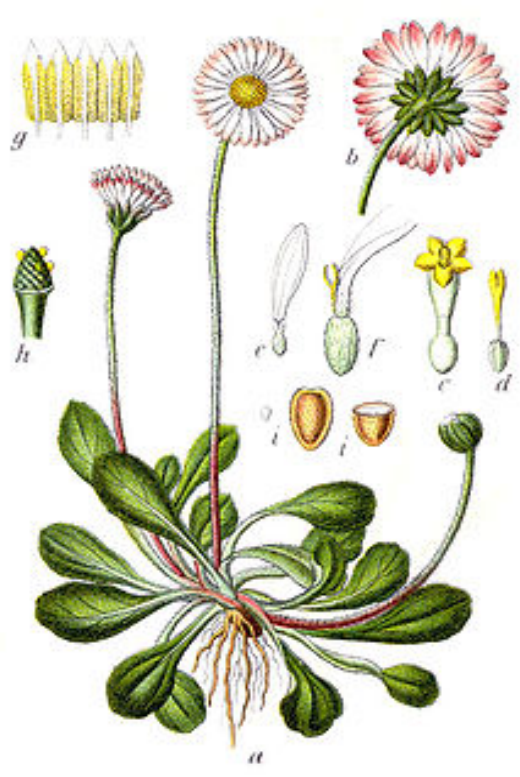


Bloom Time: May to July.

Bloom Description: White rays with yellow center.

Sun: Full sun to part shade.

Water: Medium.

Maintenance: Low.

Suggested Use: Annual, Herb, Naturalize.

Flower: Showy [12].

Fig. 36. Daisy (Bellis perennis).

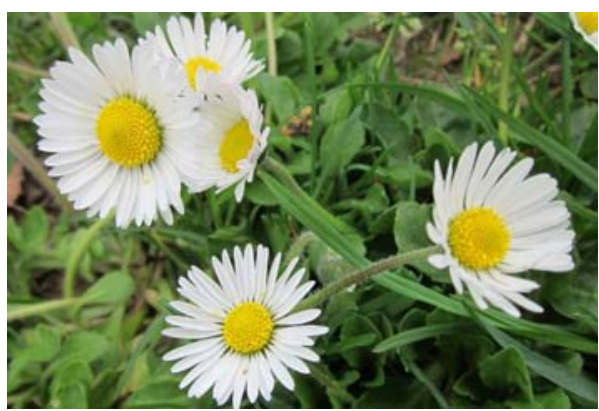

Fennel (Foeniculum vulgare). Fennel was regarded as an emblem of false flattery, as seen in Robert Greene's Quip for an Upstart Courtier (1592), "Fennell I meane for flatterers." In the Middle Ages Fennel seeds were used as appetite suppressants to aid fasting pilgrims. As such they became symbolic of things that appear to give sustenance but that in effect have none [36]. Fennel is thought to be one of the nine herbs held sacred by the Anglo-Saxons.

\section{Fennel (Foeniculum vulgare) Scientific Classification}

Kingdom: Plantae.

Division: Magnoliophyta.

Class: Magnoliopsida.

Order: Apiales.

Family: Apiaceae.

Genus: Foeniculum.

Species: F. vulgare.

Latin Name: Foeniculum vulgare.

Common Name: sweet fennel.

General Description: Foeniculum vulgare is a perennial herb,

1 to $2 \mathrm{~m}$ tall with strong anise-like odor.

Foliage: Stem striate. Leaves 3-4 pinnate;

segments filiform, up to 1.6 in. $(4 \mathrm{~cm})$ long;

leaf bases sheathing. Rays 5-30, 0.39-2.4 in. (1-6 cm) long.

Flowers: Flowers are small, yellow,

and found in large flat-topped umbels.

Blooming occurs between August and October.

Fruit: Fruit oblong to ovoid, 0.12-0.2 in. (3-5 mm) long.

Seeds (Fig. 38) ripen from September to October [5].

Fig. 38. Fennel Seeds.

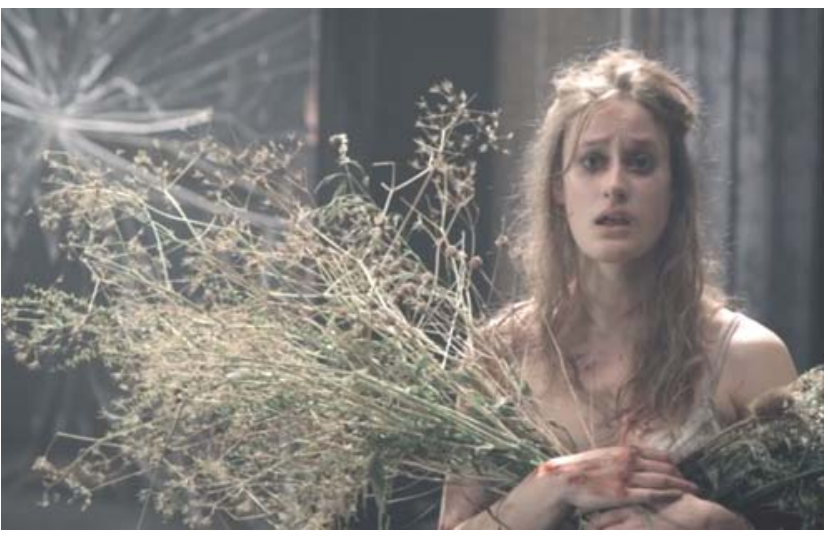

Fig. 37. Mariah Gale as Ophelia (Gregory Doran, 2009).

Columbine (Aquilegia vulgaris). The Columbine was originally a wild flower of the English fields and meadows but it became a popular Elizabethan garden flower, also known as Granny's Bonnet. Its botanical name comes from the Latin aquila meaning eagle because its petals were thought to resemble an eagle's talons. Its English name comes from the Latin for dove columba, as it was thought that its nectaries resembled the heads of doves [36]. 
In Shakespeare's day the Columbine had a number of symbolic associations. The poet and playwright George Chapman (1559-1634) seemed to suggest that it was emblematic of ingratitude, when he wrote: "What's that - a Columbine? No, that thankless flower grows not in my garden." The poet William Browne (1590-1645) suggested that the Columbine was emblematic of forsaken and neglected love:"The Columbine is tawny taken, Is thus ascribed to such as are forsaken." The Columbine was also said to be symbolic of cuckoldom as the nectaries also resembled horns [36].

\section{Columbine (Aquilegia vulgaris) Scientific Classification}

Scientific Name: Aquilegia vulgaris L (Fig. 39, 40, 41).

Family: Ranunculaceae.

Common Names: columbine, European columbine,

European crowfoot, granny's bonnet.

Type: Perennial

Height: 15 to 20 inches

When to Plant: Early spring to late summer

Flowers: May, June and July

Origin: Native to northern Africa (i.e. Algeria and Morocco) and Europe (i.e. Ireland, UK, Austria, Belgium,

Czechoslovakia, Germany, Hungary, the Netherlands, Poland, Switzerland, Albania, Greece, Italy, Yugoslavia, France, Portugal, Spain, Belarus, Estonia, Latvia, Lithuania, western Ukraine and western Russia).

Naturalised Distribution: Naturalised in some parts of Victoria and sparingly naturalised in New South Wales and Tasmania.

Naturalised overseas in large parts of eastern USA, Canada and outside its native range in Europe [3].

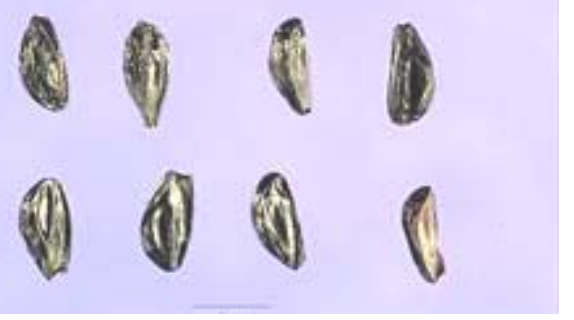

Fig. 41. Seeds.

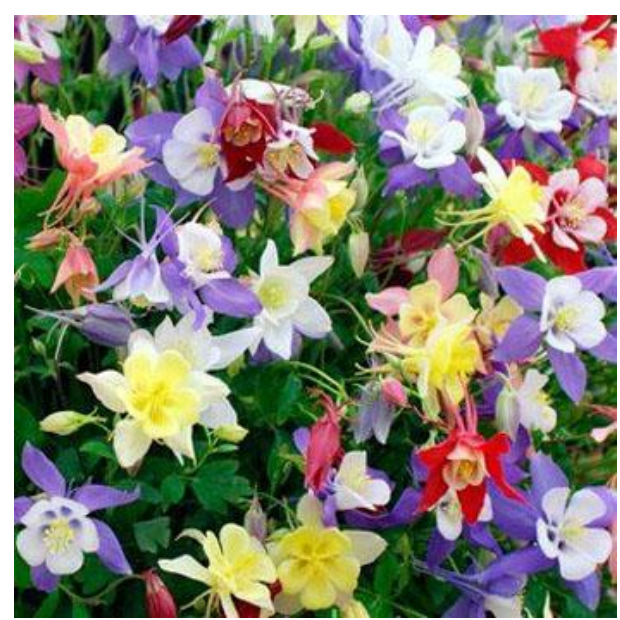

Fig. 39. Aquilegia vulgaris.

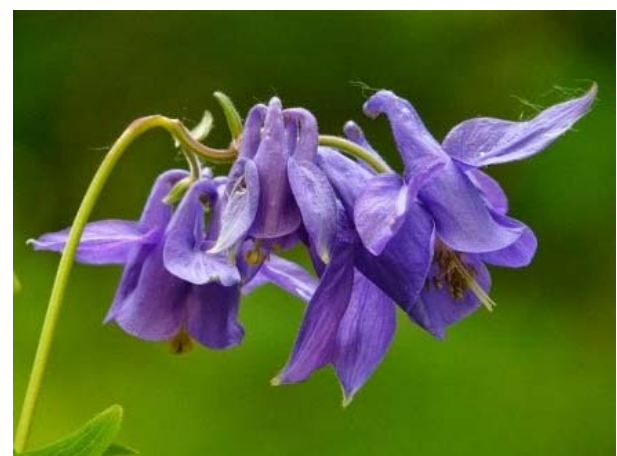

Fig. 40. Columbine petels.

Violet (Viola odorata). Violets symbolize modesty (Fig. 43). According to Greek mythology, violets were created when one of Artemis' nymphs, who had all sworn to stay maidens, was being pursued by her twin brother, Apollo. To protect her nymph, Artemis transformed her into a violet, which in turn led the violet to become a symbol of modesty [2].

There are over one hundred different species of Violet and a large number of sub-species, including the Viola tricolor or Pansy. The herbalist John Gerard 
wrote "there be made of them garlands for the head, nosegaies and poesies, which are delightfull to look on and pleasant to smel ... gardens themselves receive by these the greatest ornament of all, chiefest beauty, and most excellent grace." Francis Bacon in his Essay of Gardening wrote "that which above all others yields the sweetest smell is the violet and next to that the musk rose."

Violets are a beautiful, sweet smelling flower. Traditionally violets represented faithfulness but for Shakespeare they were also symbolic of sorrow and death.

Violets are the exact opposite of daisies. They stand for faithfulness and fidelity, but they withered when her father died, so she could not gather any to bring to the court [37].

Although prized for their beauty and their smell, Violets were also associated with melancholy and early death. This is expressed in Hamlet when Ophelia laments that she has no Violets to give to the court because "they withered when my father died" (Fig. 42) and in Laertes' wish that Violets "may spring" from Ophelia's grave [75].

A violet in the youth of primy nature

Forward, not permanent, sweet not lasting

The perfume and suppliance of a minute No more.

\section{Hamlet, Act I, Scene 3}

I would give you some violets, but they withered all when my father died.

Lay her i' th' earth Hamlet, Act IV, Scene 5

And from her fair and unpolluted flesh May violets spring.

Hamlet, Act V, Scene 1

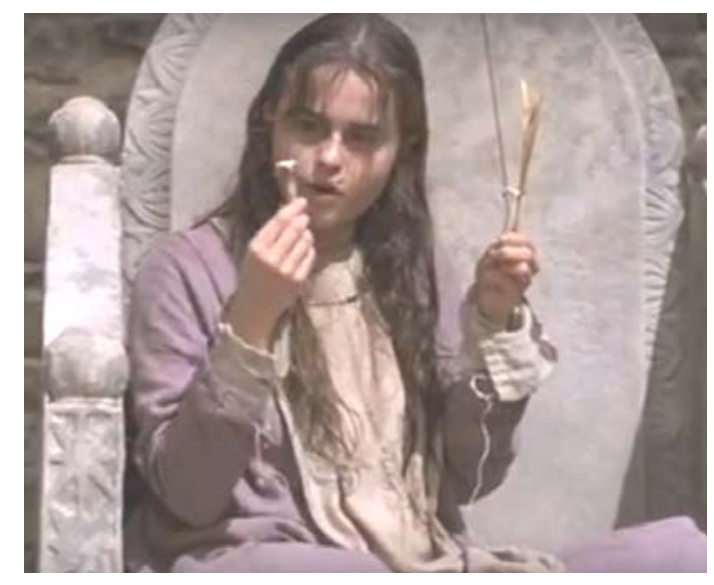

Fig. 42. Helena Bonham Carter as Ophelia (1990).

Sonnet XCIX also conveys this sense of mourning for premature death when the poet curses the Violet for having more life in it than his beloved.

The forward violet thus did I chide,

Sweet thief, whence didst thou steal thy sweet that smells If not from my loves breath? The purple pride Which on thy soft cheek for complexion dwells In my love's veins thou hast too grossly dyed.

Sonnet XCIX

I know a bank where the wild thyme blows, Where oxlips and the nodding violet grows A Midsummer Night's Dream, Act II, Scene 1

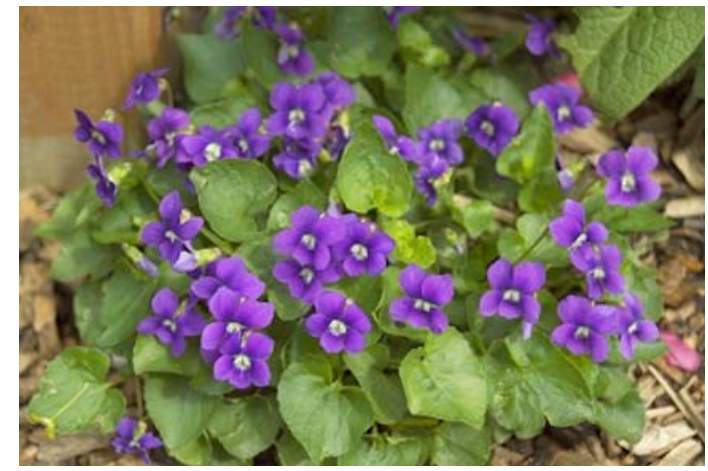

Fig. 43. Purple violets. 
Violets appear in the early Spring and then fade away, for this reason they were associated with early death, becoming "apt emblems of those who enjoyed the bright springtide of life and no more." (Ellacombe, The Plant-Lore and Garden-Craft of Shakespeare) Violets were also linked to the Underworld in Greek myth, being one of the flowers that Persephone was gathering when she was kidnapped by Hades. This scene is recounted by Perdita in The Winter's Tale.

That strain again, it had a dying fall. $\mathrm{O}$, it came o'er my ear like the sweet sound, That breathes upon a bank of violets .

Twelfth Night, Act I, Scene 1

The purple violets and marigolds, Shall as a carpet hang upon thy grave. Pericles, Act IV, Scene 1

Violets were also emblems of constancy and faithfulness, popular

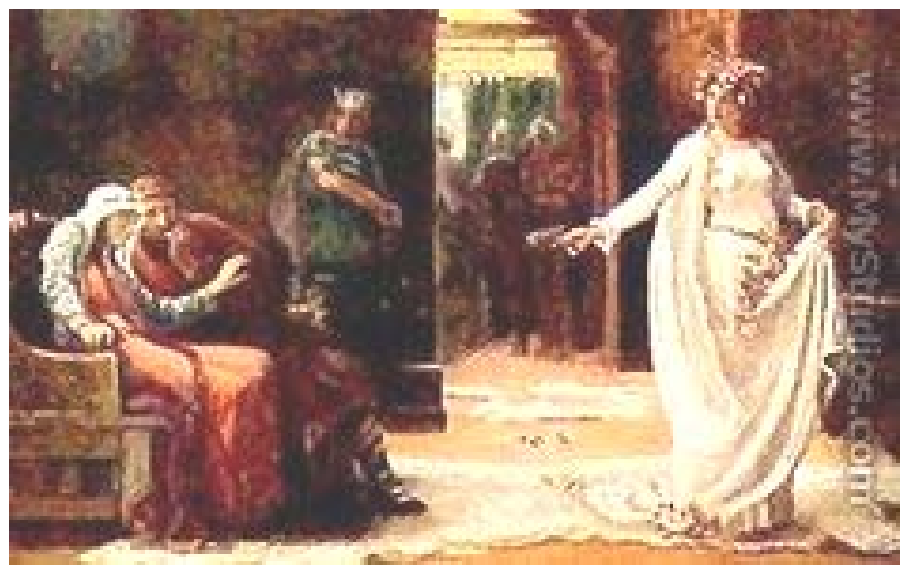
with troubadours since the fourteenth century. Fig. 44. Ophelia (1890) by Henrietta Rae [29]. A poem in a 1584 song book had this verse:

Violet is for faithfulness

Which in me shall abide

Hoping likewise that from your heart

You will not let it slide.

This meaning suggests that Ophelia's statement that the Violets had "wither'd all when my father died" had a double meaning. Not merely lamenting the death of her father but also acknowledging the lack of faithfulness and fidelity in the court, particularly evident in the actions of the new King and his Queen [75].

There are two interpretations of Ophelia's lines in Hamlet. First is that Ophelia chooses plants and flowers that symbolise her doomed romance with Hamlet. The Columbine for example being symbolic of ingratitude and forsaken love and the Fennel being symbolic of Hamlet's shallow and false love. However many historians and critics have noted that Hamlet does not appear in this scene. Instead Ophelia hands out her flowers to the court in front of the King and Queen. It is therefore more likely that Ophelia's message, shrouded in her apparent madness, is aimed at the King and his court. Here are a few suggestions as to what Ophelia is really saying when she hands out her flowers [36] (Fig. 44). 
Rosemary is for remembrance. Ophelia's plea to the court to remember has a touch of melancholy about it. As Rosemary formed part of burial wreaths it serves as a forewarning to her tragic death.

Pansies are for thoughts, closely connected to memory, of keeping people within your thoughts.

Fennel refers to the false flattery and deceit of the court.

Columbine calls the King and Queen adulterers.

Rue is a call for those around her to regret and repent their past evil deeds.

Daisies are for innocence. As I mentioned in my post on Daisies, Ophelia names the Daisy but does not hand it out, suggesting that the court lacks innocence and purity.

Violets are for faithfulness and fidelity. As Ophelia has none to give to the Queen she exposes the Queen's infidelity [36; video [1].

Thus, Ophelia's flowers, then, symbolize her many-faceted personality and desires, which have been stripped, squashed, and corrupted by society's expectations. Ophelia's imaginary flowers tie in with the thematic representation of women's issues throughout the play: Ophelia has had to change so much to survive in the world of men that she's literally driven herself mad. It is significant that later on in the play, after her suicide by drowning, Ophelia's body is found covered in "fantastic garlands" of flowers [35].

There were fantastic garlands did she come

Of crow-flowers, nettles, daisies and long purples

That liberal shepherds give a grosser name,

But our cold maids do dead men's fingers call them.

Hamlet, Act IV, Scene 7

What are the "crowflowers, nettles, daisies, and long purples" to which Queen Gertrude refers? Simply weeds and wildflowers with their own symbolic meanings. Chaucer, who was the most significant poet of the Middle Ages and considered the "Father of English Literature," uses weeds and wildflowers, but with more positive connotations than Shakespeare in Hamlet [37].

Crowflowers. The Crowflowers in Ophelia's garland have often been incontention. Some authors maintain that Shakespeare is referring to the Crowfoot 
(Ranunculus aquatilis) a member of the Buttercup family (Fig. 47). Others argue that it is the Ragged Robin (Lynchnis flos-cuculi) a pink wildflower (Fig. 48, 49) [36].
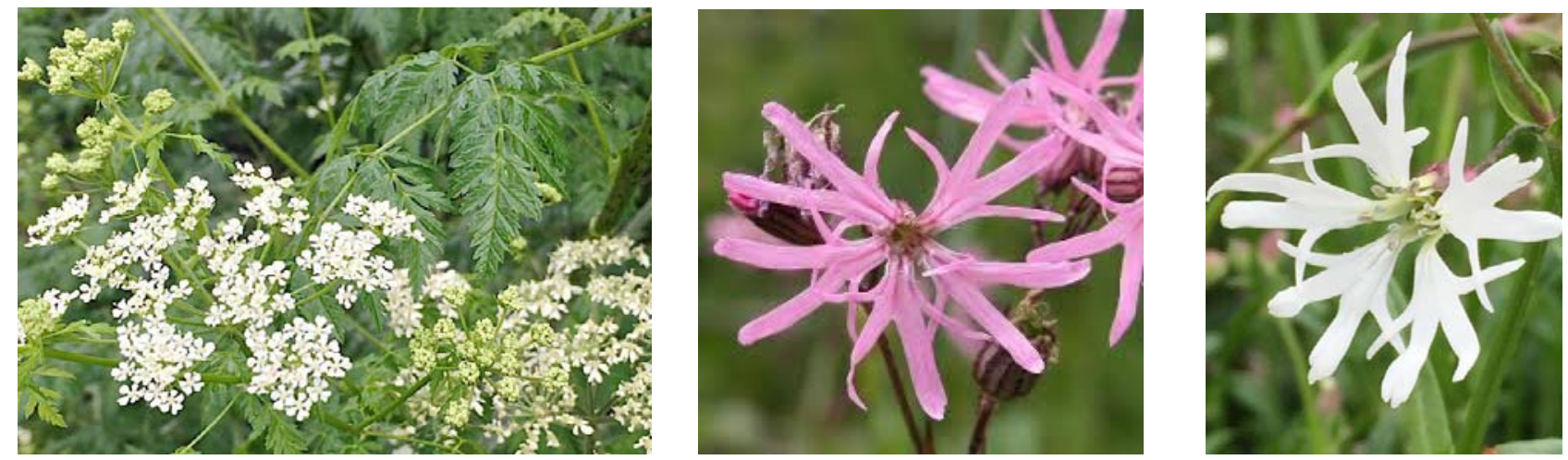

Fig. 47. Ranunculus aquatilis

Fig. 48. Lynchnis flos-cuculi (pink). Fig. 49. "White Robin".
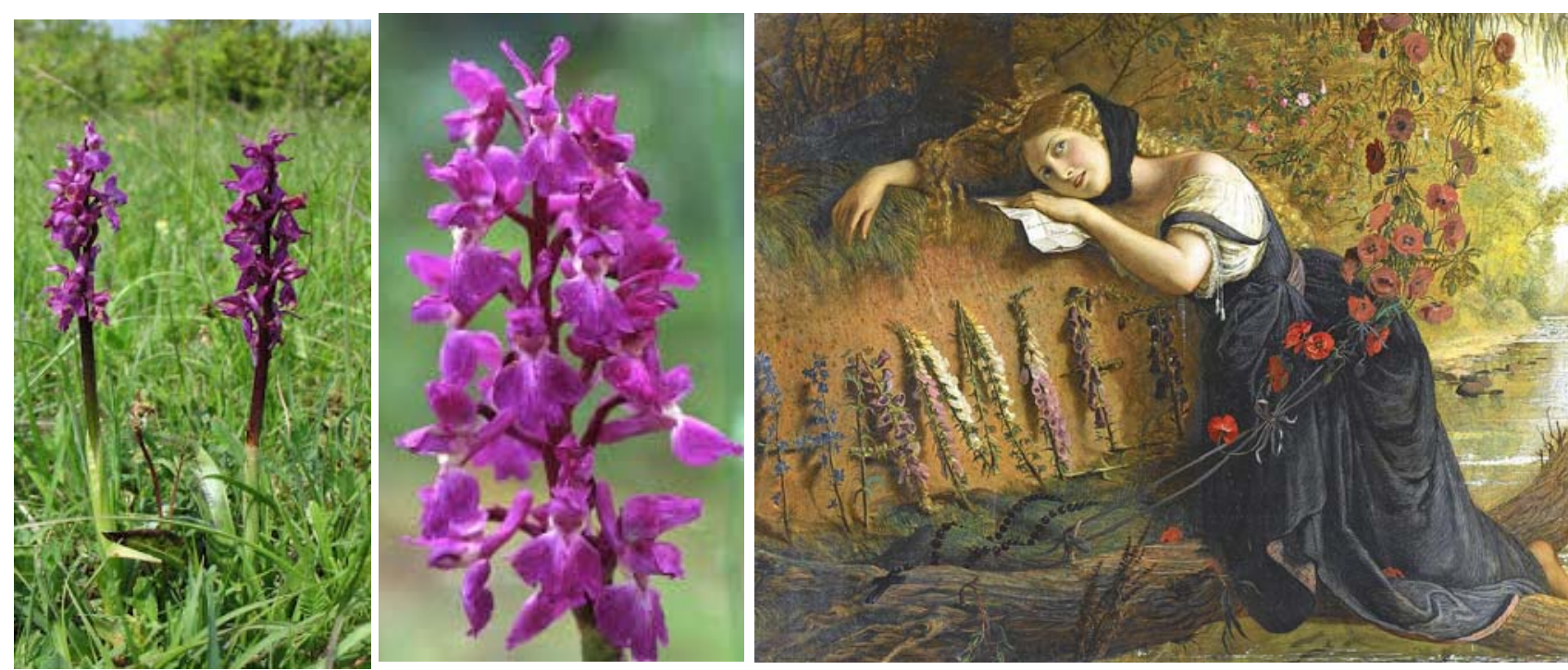

Fig. 50. Orchis mascula. Fig. 51. Orchis mascula flowers.

Fig. 52. "Ophelia" (1860)

by Joseph Severn (British, 1793-1879).

Long Purples (Orchis mascula) (Fig. 50, 51). It is generally accepted that the Long Purple that Shakespeare refers to is the Common Purple Orchis, a wildflower found in the woods, meadows and pastures. Their tall stems and purple flowers led to the name of Dead Men's Fingers, in Hamlet they add to the macabre imagery of Ophelia's death (Fig. 52). The "grosser name" that Shakespeare alludes to is their botanical name; Orchis is from the Greek meaning testicle, named so because of the shape of the plants two tubers, and mascula comes from the Latin masculus, meaning male or virile [36].

Nettles, especially the stinging nettles, represent pain (Fig. 53).

Willows with their drooping branches create the imagery of tears, sadness, or depression (Fig. 54). The weeping willow tree leaning over Ophelia is a symbol of depression (Fig. 54, 55). The weeping willow tree leaning over Ophelia is a symbol 
of forsaken love [37].

In her final moments (Fig. 33, 52, 54, 55), Ophelia chooses to ring herself in emblems of all that she was and all that she could have been, had the world around her not shrunken and shriveled her until hardly anything was left [35].
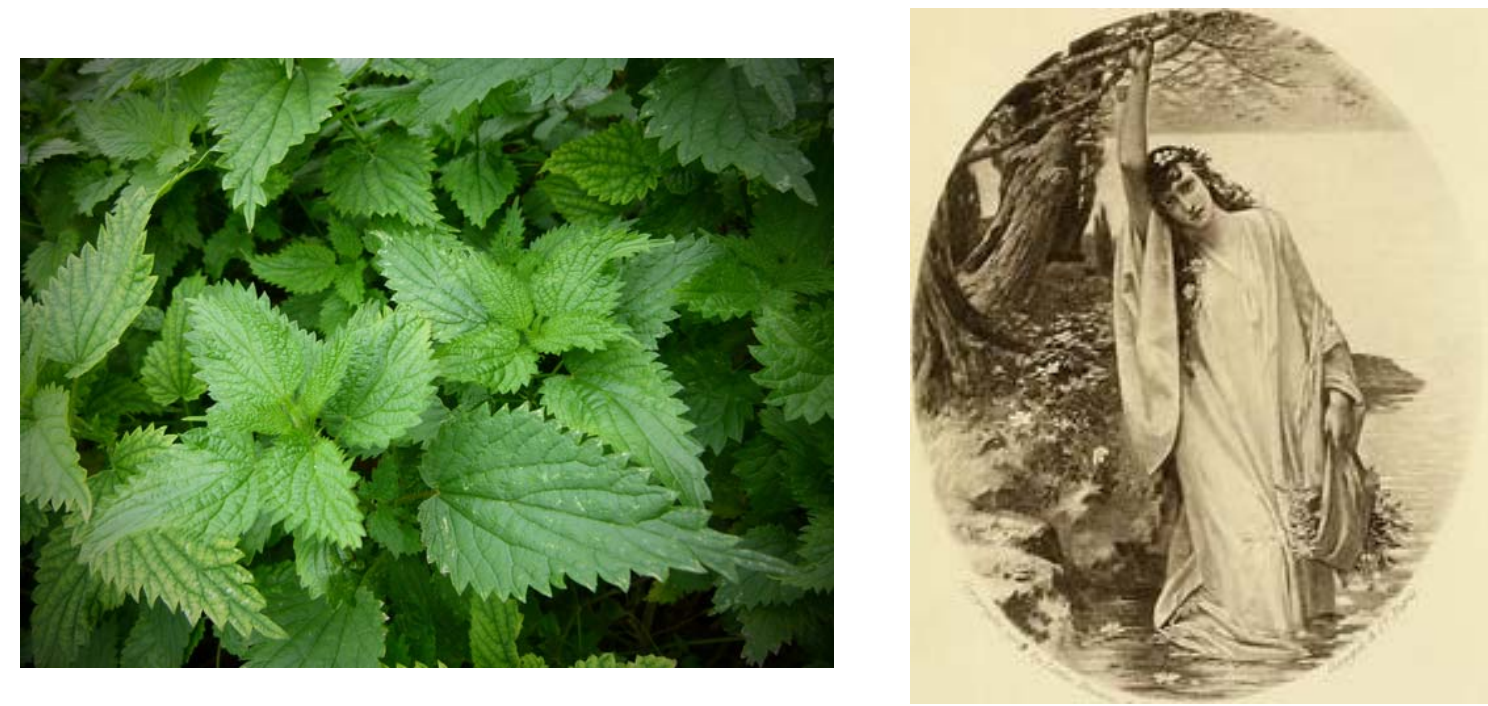

Fig. 53. Nettles.

Fig. 54. Ophelia (1853) by P.E. Rosset-Granger (French).

Also, Gertrude reports Ophelia's death in one of the most lovely, poignant, poetic speeches in all of Shakespeare. She uses nature, water, and flower imagery to show how she is now free of the cruel human world [10].

\section{QUEEN GERTRUDE}

One woe doth tread upon another's heel,

So fast they follow; your sister's drown'd, Laertes.

LAERTES

Drown'd! O, where?

QUEEN GERTRUDE

There is a willow grows aslant a brook,

That shows his hoar leaves in the glassy stream;

There with fantastic garlands did she come Of crow-flowers, nettles, daisies, and long purples

That liberal shepherds give a grosser name,

But our cold maids do dead men's fingers call them:

There, on the pendent boughs her coronet weeds

Clambering to hang, an envious sliver broke;

When down her weedy trophies and herself

Fell in the weeping brook.

Her clothes spread wide;

And, mermaid-like, awhile they bore her up:

Which time she chanted snatches of old tunes;

As one incapable of her own distress,

Or like a creature native and indued

Unto that element: but long it could not be

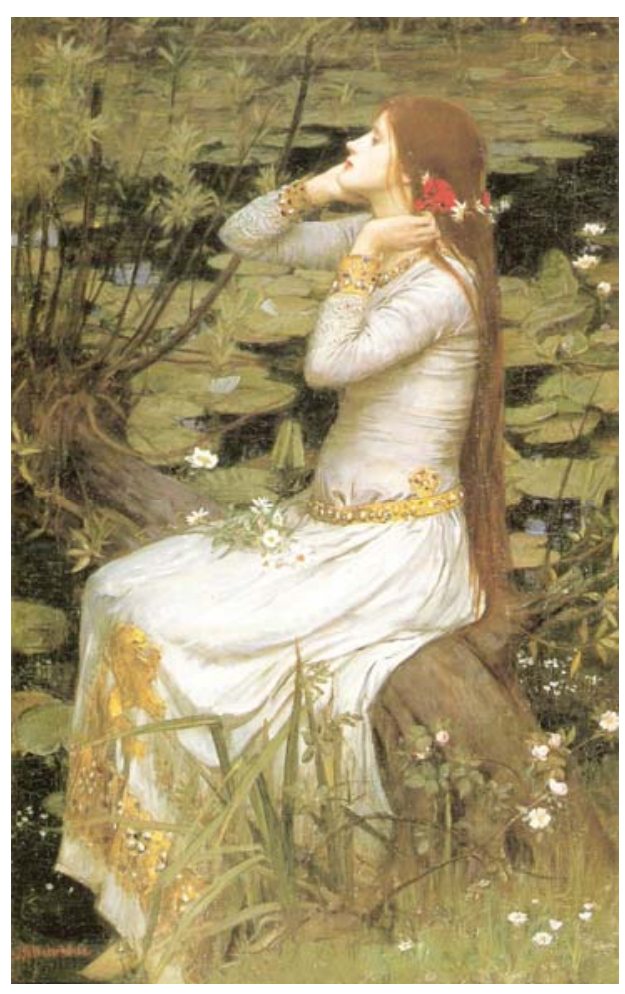

Fig. 55. Ophelia (1894)

by John William Waterhouse [80]. 
Till that her garments, heavy with their drink, Pull'd the poor wretch from her melodious lay To muddy death [60, p. 114].

Her death confirms her alienation from all the men in her life, who failed her. That is why it is reported by Gertrude and in such a strikingly beautiful way. Both these heroines face death as a result of the power play of men around them.

We want to tell that prominent composers dedicated their musical masterpieces to the image of Ophelia.

"If music be the food of love, play on; Give me excess of it, that, surfeiting, The appetite may sicken, and so die. That strain again! it had a dying fall: O! it came o'er my ear like the sweet sound That breathes upon a bank of violets, Stealing and giving odou", wrote William Shakespear 400 years ago [57].

Johanned Brahms (Fig. 56) wrote five songs for an 1873 performance of Hamlet by actress Olga Precheisen in Prague. They were published after his death, and are based on Ophelia's poetry in Shakespeare's play (video [6]).
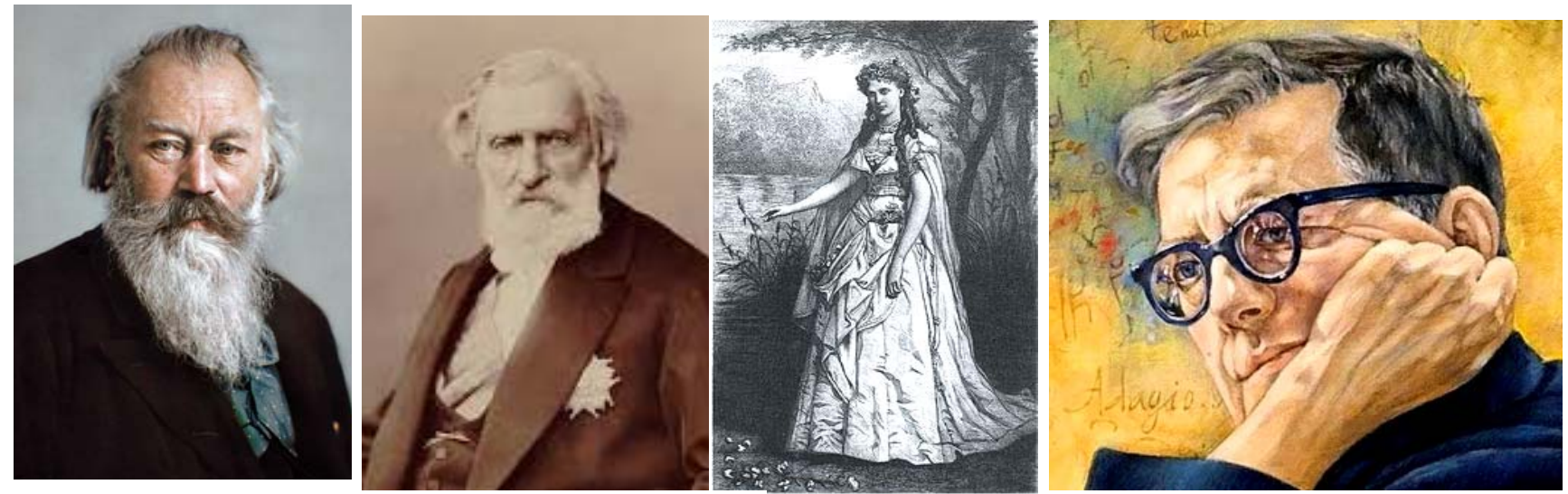

Fig. 56. Johannes Brahms Fig. 57. Ambroise Thomas. Fig. 58. Christine Nilsson (1889)

(1894) as Ophélie (1868, Paris)

Fig. 59. D Shostakovich

With Shakespearian operas all the rage in Paris during the 19th century, Ambroise Thomas (Fig. 57) and his librettists Michel Carré and Jules Barbier adapted "Hamlet" in 1868 to create a romantic spectacle in which the character of Ophélie shines with a haunting radiance (video $[40 ; 67])$. With its virtuosic arias, stunning ensembles and vivid orchestration - with the colourful addition of the newly invented saxophone - Thomas composed one of the most successful operas in the French repertoire (video [66; 69]).

The work was premiered at the Paris Opéra(Salla Le Peletier) on 9 March 1868. Among the noted singers in the original cast were Jean-Baptiste Faure as Hamlet and Christine Nilsson as Ophelia (Fig. 58). The opera was staged, sung in Italian, at the Royal Italian Opera, Covent Garden (later the Royal Opera House, 
Covent Garden) in June 1869 [26].

D. Shostakovich turned to Shakespeare's plays too (Fig. 59). He composed music for over more than thirty films. In most cases, he provided wonderful music. His two scores for the director Kosintsev - Hamlet (1964) and Hamlet- ballet [42; 77] (Fig. 60, 61, 62, 63).
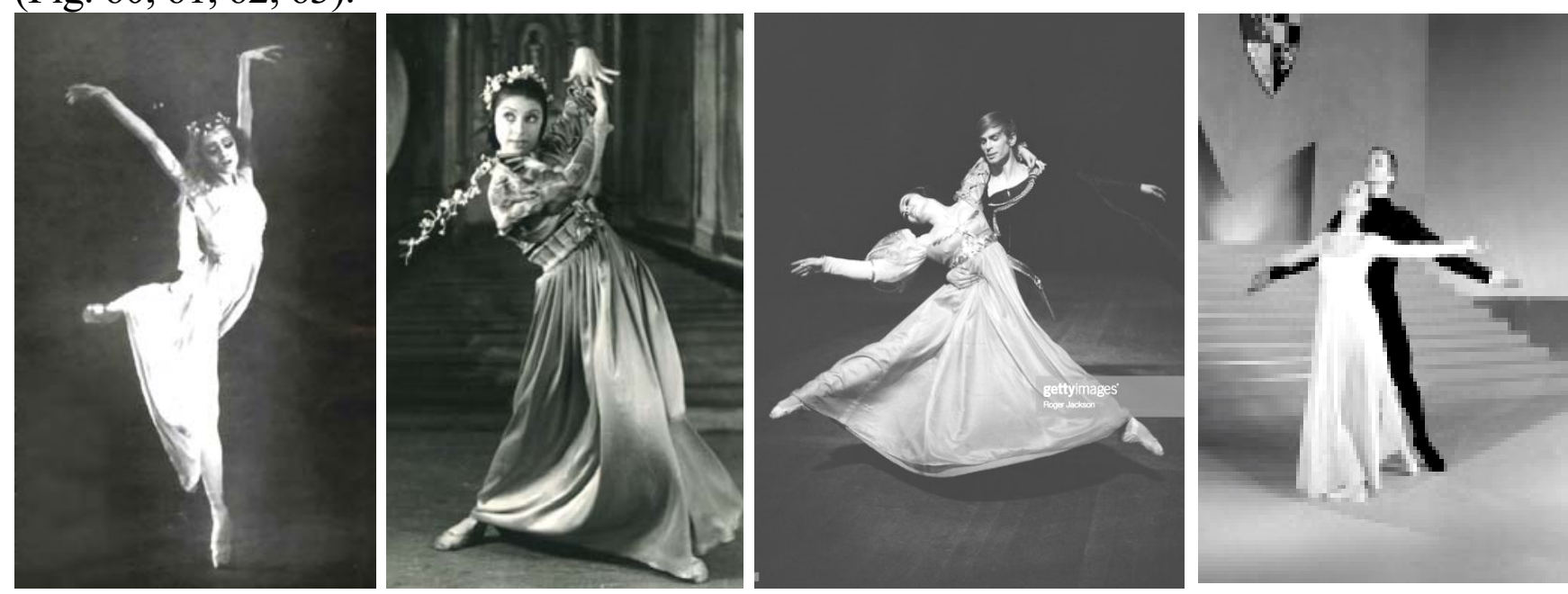

Fig. 60. U. Lopatkina Fig. 61. Margot Fonteyn (1994) [73].

(1942)

Fig. 62 Lynn Seymour and Fig. 63. I.Kholina and Rudolf Nureyev (1962) [54[. M. Liepa (1961) [64].
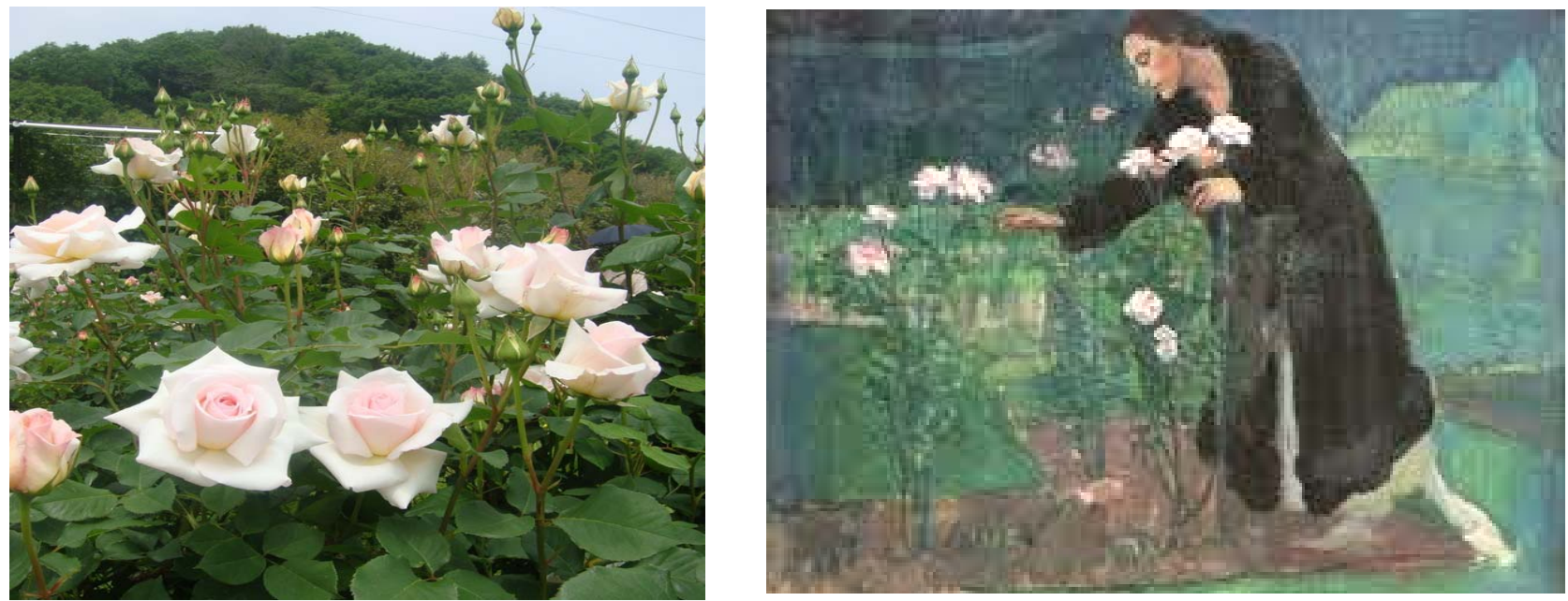

Fig. 64. The Roses Ophelia. $\quad$ Fig. 65. "The Ophelia Rose" (1918) by Violet Oakley.

In the end, we'll remember the Ophelia rose named after Shakespeare's heroine (Fig. 64, 65, 66, 71). Its shapely buds opening to highly fragrant, rich, flesh pink flowers with deeper shadings with slight lemon tints in the centre of each bloom. Good foliage. Excellent for cut flowers and for growing in a container. For best results, extra care and feeding is required. Bred by William Paul [34; 76] (Fig. 67, 68).

William Paul devoted attention to the improvement of other plants, such as ollyhocks, asters, hyacinths, phloxes, camellias, zonal pelargoniums, hollies, ivies, 
hshrubs, fruit-trees, and Brussels sprouts [44] and wrote some catalogs, books abote rose gardening $[34 ; 41 ; 42]$. We concentrated upon the rose introduced by $19^{\text {th }}$ century breeders in particular, those bred by William Paul and his successors. Hybrid Teas certainly dominated in the 1920s and 1930s and sometimes too, the 1900s.
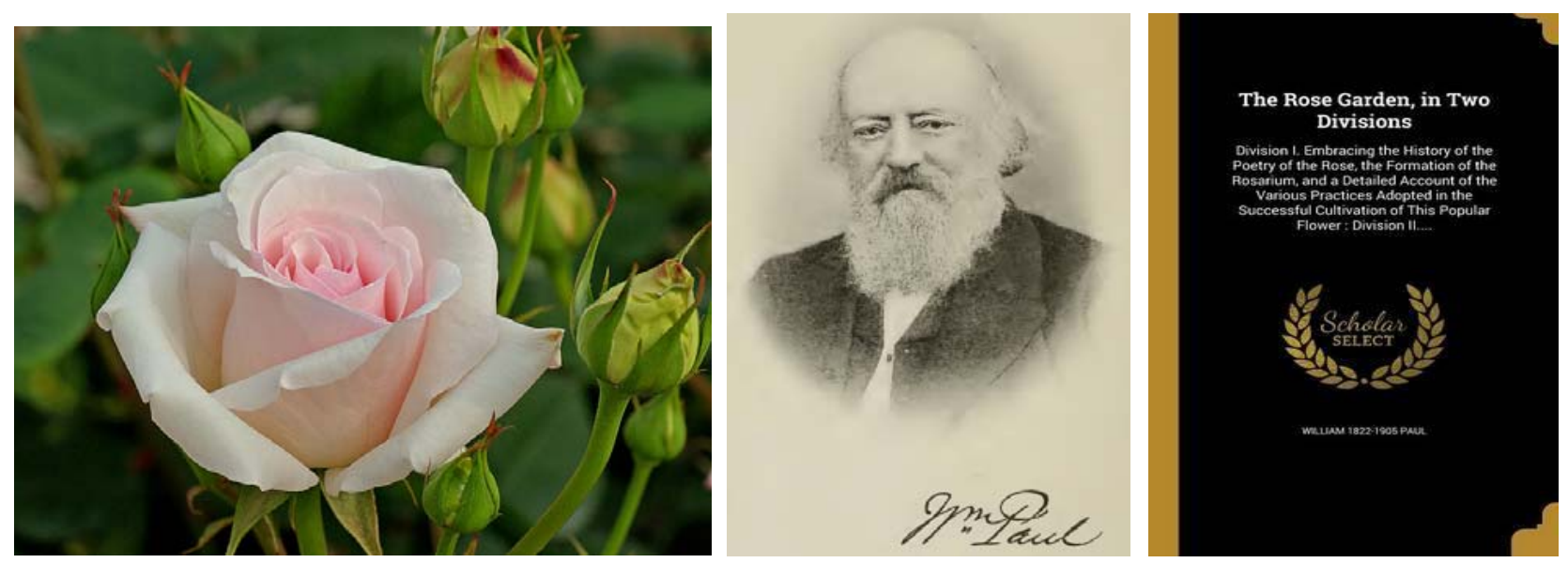

Fig. 66. The Ophelia rose (1912). Fig. 67. William Paul (1822-1905). Fig. 68. "The Rose Garden".

Parentage of the the Ophelia rose (Fig. 45, 47, 52, 53) was seedling of the rose Antoine Rivoire (Fig. 69) [50; 83].
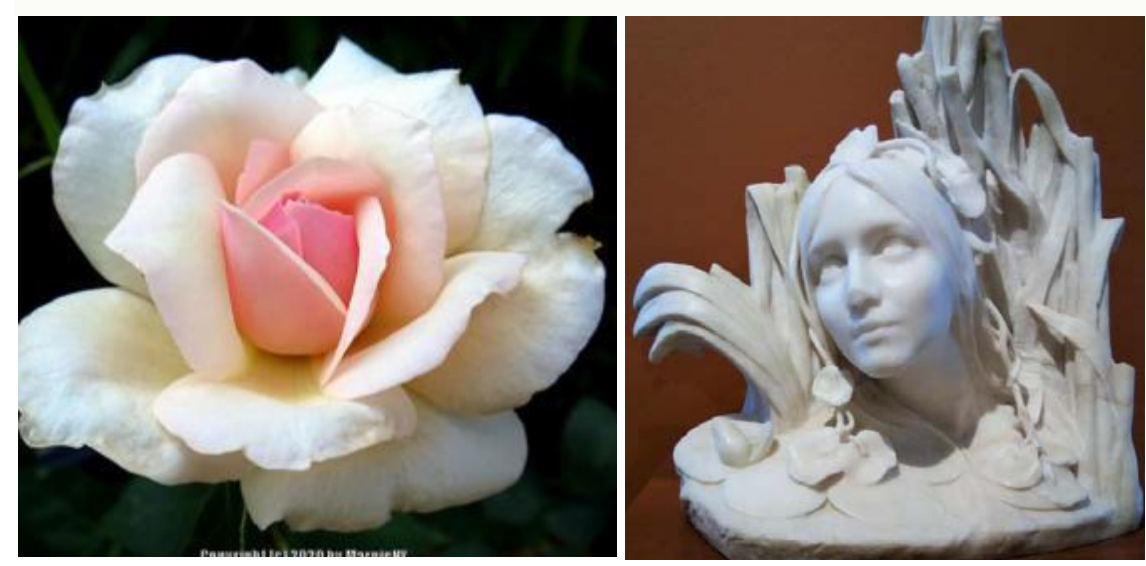

Fig. 69. The rose Antoine Rivoire. Fig. 70. Ophelia (1880), marble, by M.Antokolskii.

\section{The Rose "Ophelia" Characteristics}

Bred by Unknown French Breeder(s) (France, before 1912). Introduced in United Kingdom by William Paul \& Son in 1912 as 'Ophelia'.

Introduced in Australia by H. Kemp in 1913 as 'Ophelia'.

Family: Rosaceae

Genus: Hybrid Tea Rosa.

Rose bloom color: Light pink [Fig. 71, 72].

Plant Type: Bush, upright, Shrub.

Flower type: Medium to large, semi-double to double, borne mostly solitary, in small clusters bloom form.

Bloom size: Large: 4-5".

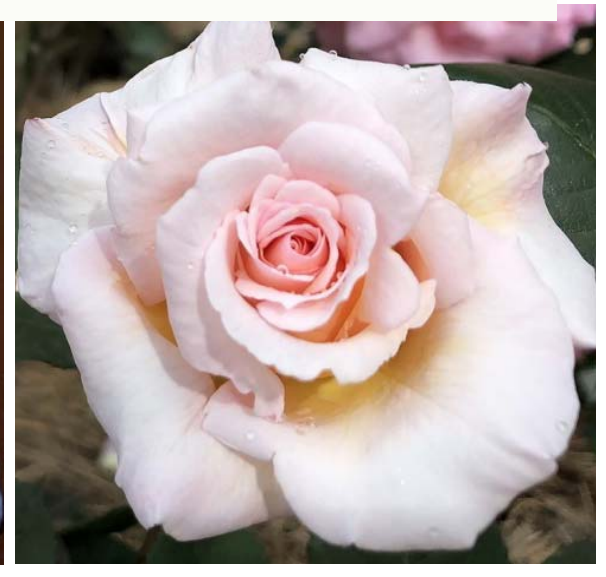

Fig. 71. The Ophelia rose [34].

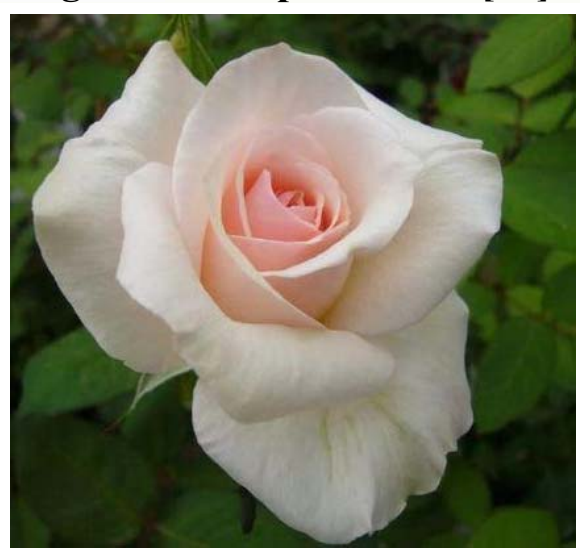

Fig. 72. A flower. 
Bloom shape: High-centered.

Petal count: full: $26-40$ petals [Fig. 54].

Rebloom: Good

Extra Color Info: Salmon-pink, with yellow center

Flowering: Blooms in flushes throughout the season double [Fig. 71, 72, 74, 75].

Wildlife: Friendly.

Thorns: A varied thorn count.

Fragrance: Strong fragrance.

Height of $2^{\prime}$ to $41^{\prime} 4^{\prime}(60$ to $130 \mathrm{~cm})$.

Width of $18 "$ to $2^{\prime}$ (45 to $60 \mathrm{~cm}$ )

Heat Zones: $5 b$ through 9a.

Life cycle: Perennial.

Sun Requirements: Full Sun.

Leaves: Deciduous.

Flowers: Showy. Fragrant.

Flower Time: Spring. Summer. Fall.

Wildlife Attractant: Bees.

Uses: Cut Flower, growing in pots [3; 4; 5].

Parentage: Seedling of Antoine Rivoire (breeder Joseph Pernet-Ducher, 1895) [50; 83].

Child plants: 12 child plants $[8 ; \mathbf{5 1}]$.

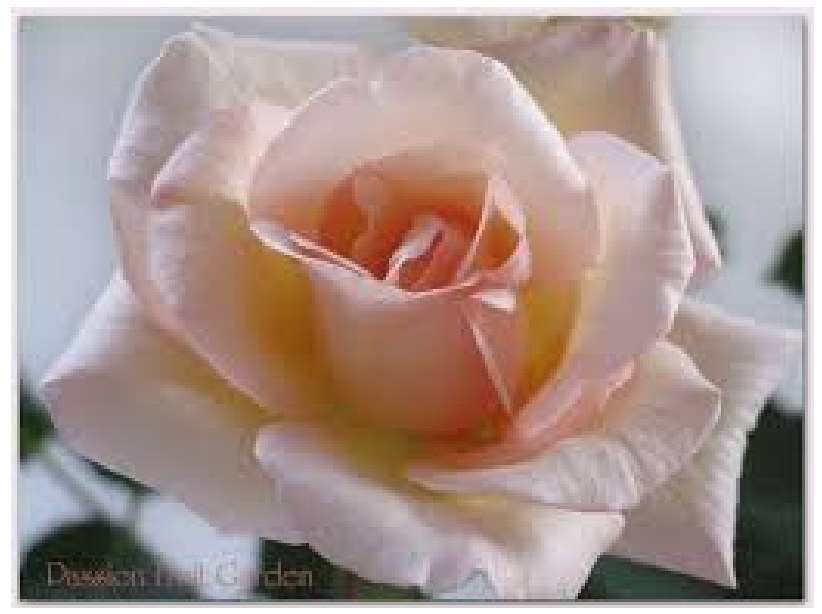

Fig. 75. Flowering.

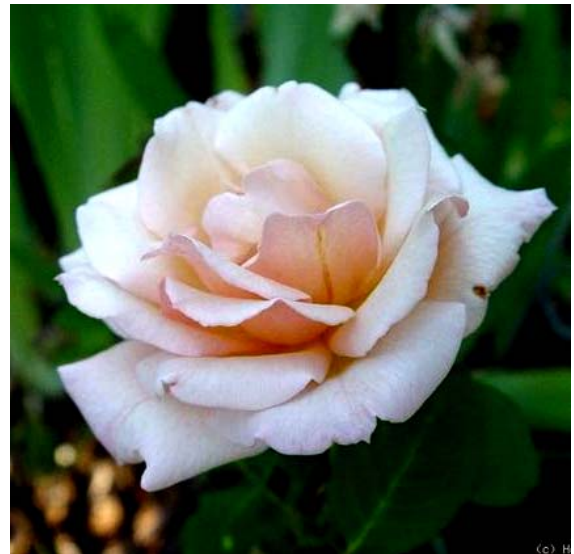

Fig. 74. Petels.

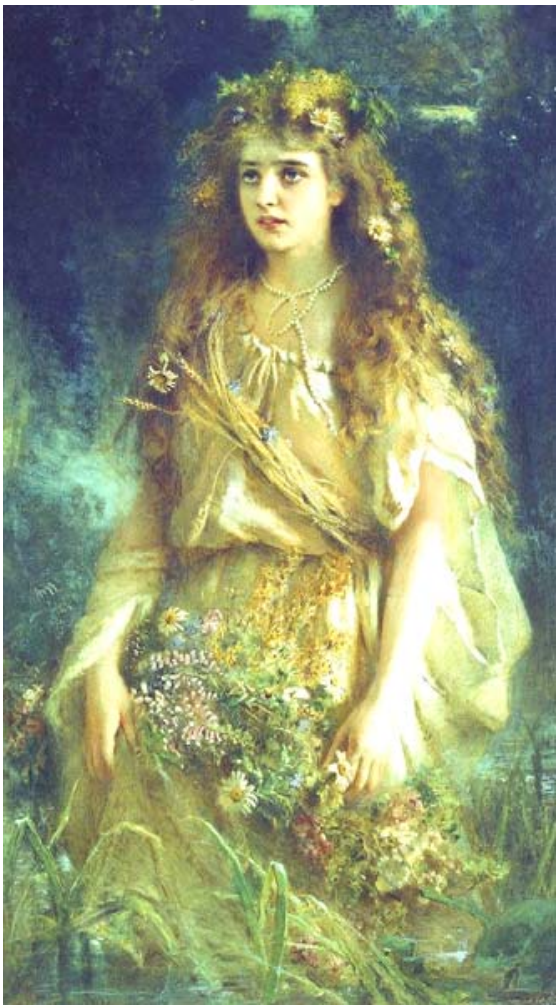

Fig. 76. Ophelia by K. E. Makovsky.

\section{Bibliography}

1. Act IV, scene v Ophelia's Flowers. URI : https://slideplayer.com/slide/9724039/

2. Aphrodite, Gilda, and the violets.

URI :

HTTPS:/ROSYBVM.COM/2020/02/11/APHRODITE-GILDA-AND-THE-VIOLETS/

3. Aquilegia vulgaris L.URI : https://www.gbif.org/species/3033191

4. Asteraceae. URI : https://en.wikipedia.org/wiki/Asteraceae

5. Bean Caitlin, Russo Mary J., and TunyaLee Martin. Foeniculum vulgare. Global Invasive Species Team, The Nature Conservancy. URI : https://wiki.bugwood.org/Foeniculum_vulgare

6. Brahms. Ophelia-Lieder (soprano: Magdalena Kozena). URI : https://www.youtube.com/watch?v=Zt6qmCdTUmU

7. Character

Analysis

Ophelia.

URI :

https://www.cliffsnotes.com/literature/h/hamlet/character-analysis/Ophelia

8. Child plants of Rose (Rosa 'Ophelia'). URI : https://garden.org/plants/parentage/2382/

9. Columbine Flower - Meaning, Symbolism and Colors. URI :

https://flowermeanings.org/columbine-flower-meaning/ 
10. Conner Marc C. Gertrude and Ophelia: What Their Lines in Hamlet Reveal. URI : https://www.thegreatcoursesdaily.com/gertrude-and-ophelia-what-their-lines-in-hamlet-reveal/

pansies.html

11. Daisies and Pansies. URI : https://bardgarden.blogspot.com/2014/11/daisies-and-

12. Bellis

perennis.

URI:

https://www.missouribotanicalgarden.org/PlantFinder/PlantFinderDetails.aspx?kempercode=b749

13. Ennio Morricone - Hamlet Suite (1990). Krakov, Congress Center, May 29, 2015. URI : https://www.youtube.com/watch? $\mathrm{v}=\mathrm{mtQNrD} 9 \mathrm{CP}-$

8\&list=PLbChdS3BkjrsQrg_XYk3jcUNhpmgtBcoD\&index $=85$

14. Everything you need to know about rosemary. URI : https://www.medicalnewstoday.com/articles/266370\#_noHeaderPrefixedContent

15. Gibson. Hamlet 3.1. Movie (Franco Zeffirelli, 1990). URI :

https://www.youtube.com/watch?app=desktop\&v=fO-wxlavDQI

16. Great Russian actress plays Ophelia (English subs), 1964, G. Grigori Kozintsev. URI : https://ok.ru/video/10112992517 with English subtitles

17. Growing Rosemary is SO Easy, You'll Have to Try To Kill It. URI : https://www.youtube.com/watch?v=brbPNLVF9b4 with English subtitles

18. Hamlet. Act 1, Scene 3 Summary \& Quotes. URI : https://study.com/academy/lesson/hamlet-act-1-scene-3-summary-quotes.html

$\begin{array}{llllll}\text { 19. Hamlet. } & \text { Act } & 3 & \text { scene } & 1 & \text { (movie }\end{array}$ URI : https://www.youtube.com/watch?v=7PcUQyXNYe0

URI : https://www.youtube.com/watch?v=cWpa49zCphs

20. Hamlet (1948) Act 3. Scene 1. URI : https://www.youtube.com/watch?v=9DcoiAAuoeg

21. "Hamlet" (English Hamlet) - a feature film directed by Laurence Olivier, 1948 film adaptation of the tragedy of the same name by William Shakespeare. URI: https://ok.ru/video/1412032039424

22. Hamlet. In Act 4, Scene 5, Ophelia gives flowers. What flowers does she give to specific characters? Is there a "method in [her] madness"? URI : https://www.enotes.com/homeworkhelp/scene-5-act-4-ophelia-gives-flowers-what-can-you-311008

23. Hamlet, Prince of Denmark. Audible Audiobook. William Shakespeare (Author), B. J. Harrison (Narrator).

URI : https://www.amazon.com/gp/product/B00A7G6WF4/ref=as li qf sp asin_il tl?ie=UTF8\& 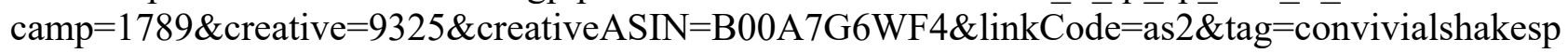 eare-20\&linkId=3XFA7XLJBHVT7HKP (in English)

24. Hamlet (2018). Shakespeare's Globe. Trailer. URI :

https://www.youtube.com/watch?v=V-C2ZaK04v8

25. Hamlet: The life of Ophelia in 4 different film versions. URI : https://www.youtube.com/watch?v=GC51mDDs4ZQ

26. Hamlet (Thomas). Opera. URI : https://en.wikipedia.org/wiki/Hamlet_(Thomas)

27. Holland P. (2017). Film, Music and Shakespeare: Walton and Shostakovich. In B. Barclay \& D. Lindley (Eds.), Shakespeare, Music and Performance (pp. 195-208). Cambridge: Cambridge University Press. doi:10.1017/9781316488768.014

28. Homegrown / Foraging for Backyard Edibles. URI :

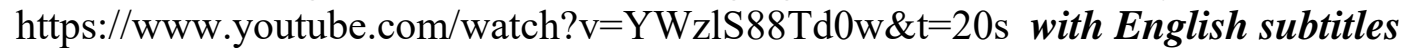

29. Is there a Willow? Paintings of Ophelia from 1890. The Eclectic Light Company. August 4, 2019. URI : https://eclecticlight.co/2019/08/04/is-there-a-willow-paintings-of-ophelia-from-1890/

30. Kate Winslet Singing. Hamlet (USA/UK, 1996) Director: Kenneth Branagh Clip: Ophelia (Winslet) singing. URI : https://www.youtube.com/watch?v=74YTzl7vFEs\&list=PLLN_zHJZDMjOB7Ww4z38JvP1COrzr brla\&index $=7$

31. Mel'nyk Vira, Pet'ko Lyudmila. Music as Symbolism or as a Metaphor in Shakespeare's Plays / Historical and pedagogical studies: scientific journal; edited by N.M. Demyanenko. Kyiv: 
Dragomanov National Pedagogical University Publishing House, 2014. Issue. 8. Pp. 197-202.

32. Morgun M., Pet'ko L. The Rose "Falstaff" and English Literature // abstracts of the In International Science Conference on Multidisciplinary Research (Berlin, January 19-21, 2021), Germany, Berlin. 2021. 1115 p. Pp. 119-129.

33. Ophelia URI: https://en.wikipedia.org/wiki/Ophelia

34. Ophelia (Bush Rose). URI :

https://www.classicroses.co.uk/roses/ophelia-bush-rose.html

35. Ophelia's Flowers (Symbol

https://www.litcharts.com/lit/hamlet/symbols/ophelia-s-flowers

Analysis). $\quad$ URI :

36. Ophelia's Flowers. URI : https://bardgarden.blogspot.com/2015/01/opheliasflowers.html

37.

Ophelia's

Flowers.

URI :

https://invitationtothegarden.wordpress.com/2019/06/27/ophelias-flowers/

38. Ophelia, Helena Bonham-Carter English. URI :

https://www.youtube.com/watch? $\mathrm{v}=$ TfesP-

eKJF8\&list=PLbChdS3BkjrsQrg XYk3jcUNhpmgtBcoD\&index $=9$

39. Ophelia goes mad (Ophelia: Daisy Ridley). Movie 2018. URI : https://www.youtube.com/watch?v=71D9zDi519M with English subtitles

40. Ophelia's Mad Scene: Hamlet by Thomas | Operalia 2014. Amanda Woodbury (soprano) singing 'A vos jeux' in the Operalia Finals. Winner of 2nd Place and Audience Choice awards. URI : https://www.youtube.com/watch?v=PFOSg8psOA4
41. Paul
and
Son
(after
1906),
William.
URI :

https://www.helpmefind.com/gardening/l.php?1=7.5933

42. Paul William. The rose garden. London, 1848. Part 3. Contributor: University of $\begin{array}{lll}\text { California Libraries. } & \text { Sponsor } \\ \text { https:/www liveinternetru/users/bogsve/post410334181/ }\end{array}$

43. Pet'ko Lyudmila. About socio-culturological content in teaching subjects / Lyudmila Pet'ko // Development strategy of science and education: Collection of scientific articles. - Fidelite editions, Namur, Belgique, 2017. P. 316-319.

44. Pet'ko L.V. Development of students' cognitive activity in foreign language teaching for professional purposes by using analogy method / Actual problems of globalization: Collection of scientific articles. - Midas S.A., Thessaloniki, Greece, 2016. Pp. 232-237.

URI http://enpuir.npu.edu.ua/handle/123456789/11301

45. Pet'ko L.V. Brainstorming and the formation of professionally oriented foreign language teaching environment in the conditions of university (for the specialties 023 «Fine Arts» and 022 «Design») // Economics, management, law : challenges and prospects: Collection of scientific articles. Psychology. Pedagogy and Education. - Discovery Publishing House Pvt. Ltd., New Delhi, India. 2016. Pp. 214-217.

46. Pet'ko Lyudmila. Developing students' creativity in conditions of university // Research: tendencies and prospects: Collection of scientific articles. - Editorial Arane, S.A. de C.V., Mexico City, Mexico, 2017. Pp. 272-276.

47. Pet'ko L. Multicultural upbringing of students and the formation of professionally oriented foreign language teaching environment // Perspectives of research and development : Collection of scientific articles. - SAUL Publishing Ltd, Dublin, Ireland, 2017. Pp. 164-170.

48. Pet'ko L. V. Teaching of students' professionally oriented foreign language writing in the formation of professionally oriented foreign language learning environment // Economics, management, law: innovation strategy: Collection of scientific articles. Henan Science and Technology Press, Zhengzhou, China, 2016. Pp. 356-359.

49. Pet'ko L., Turchynova G., Sokolov T. The William Shakespeare Rose and the Rose in Shakespeare's works // Impact of modernity on science and practice: Abstracts of XVIII International Scientific and Practical Conference. Boston, USA 2020. Pp. 116-125.

50. Rose (Rosa 'Antoine Rivoire'). URI : https://garden.org/plants/view/1740/Rose-Rosa- 
Antoine-Rivoire/

51. Rose (Rosa 'Ophelia'). URI : https://garden.org/plants/view/2382/Rose-Rosa-Ophelia/

52. Roses, Clematis and Peonies. URI : https://www.helpmefind.com/rose/l.php?1=2.4561

53. Rosemary and Rue. URI : https://bardgarden.blogspot.com/2014/10/rosemary-and-rue.html

54. Rudolf Nureyev.

"Hamlet"

D. Shostakovich

URI : https://www.youtube.com/watch?v=KleNsk-tdZI

55. Rue (Ruta graveolens). URI : https://www.healthbenefitstimes.com/rue/

56. Skorokhod. D. The Language Of Flowers / D. Skorokhod, L. Pet'ko // Strategies for the development of modern education and science: I international scientific practice. Internet conference (Berdyansk, February 28, 2020). - Berdyansk: BSPU, 2020. P. 10-16.

57. Shakespeare quotes about classical music. URI : https://www.classicfm.com/discovermusic/latest/shakespeare-quotes-music/

58. Shakespeare; The Globe Theatre London tour. URI :

https://www.youtube.com/watch? $\mathrm{v}=\mathrm{m} 3 \mathrm{VGa}$ Fp3zI with English subtitles

59. Shakespeares' flowers. URI : https://www.soane.org/features/shakespeares-flowers

60. Shakespeare William. The Tragedy of Hamlet, Prince of Denmark. 1999 version by Jon Bosak 143 p. URI : https://www.w3.org/People/maxf/XSLideMaker/hamlet.pdf

61. Shevchenko V., Pet'ko L. William Shakespeare rose named after 'British Man of the Millennium' // Fundamental and applied research: current issues, achievements and innovations: materials of the first international scientific-practical Internet conference (Berdyansk, March 27, 2020). Berdyansk. 2020. Pp. 37-44.

62. Stepanchenko D., Pet'ko L. The rose Sweet Juliet is a tribute to young love // Current issues of science: materials of the first international scientific practice. Internet conference (Berdyansk, April 30, 2020). Berdyansk: BSPU, 2020. - 202 p. Pp. 36-46. URI: http://enpuir.npu.edu.ua/handle/123456789/28862

63. Shostakovich D. "Hamlet" ballet world premiere March 11, 2015. URI : https://www.youtube.com/watch?v=vj7k94wrlZA

64. Shostakovich D. Hamlet by Maris Liepa (1969). Production: Creative Association "Screen". URI : https://www.youtube.com/watch?v=bxyqPAHJIEk

65. To be or not to be - Kenneth Branagh HD (Hamlet, 1996 movie. Director: Kenneth Branagh). URI : https://www.youtube.com/watch? $=$ SjuZq-8PUw0 with English subtitles

66. Thomas Ambroise. Hamlet (opera). Filmed on 19 and 21 December 2018 at the Opéra Comique, Paris, France. URI : https://www.youtube.com/watch?v=FkPV74kGP6M

67. Thomas. Hamlet. Aria "Della pazzia" Natalie Dessay, 2000. URI : https://www.youtube.com/watch?app=desktop\&v=8BpAJ-SXfCQ

68. Thomas. Hamlet. Natalie Dessay "Pâle et blonde" (scene - part 2), 2000. URI : https://www.youtube.com/watch?v=k4XJGjxJUD4

69. Thomas: Hamlet. Ophelia's Mad Scene - Sabine Devieilhe, 2018. URI : https://www.youtube.com/watch?v=8Iyw2ESUt3M

70. Turchynova Ganna. Training Teachers of Natural Sciences in the Context of the New Ukrainian School // Education, Law, Business: Collection of scientific articles. - Cartero Publishing House, Madrid, Spain, 2019. - 200 p. P. 175-178.

71. Turchynova G., Alieksieienko T., Karaman S., Kushniruk S. and Hladun T. Simulation of a Cloud Oriented Learning Environment at an Educational Establishment. The 36th IBIMA Conference (Granada, Spain, 4-5 November, 2020).

72. Turchynova G, Pet'ko L., Holovko T. Studying Gardens of the World with Students of Higher Education Establishments. Intellectual Archive. Toronto: Shiny Word.Corp. (Canada). 2020. Vol. 9 (October/December). No. 4. Pp. 94-107.

73. Uliana Lopatkina as Ophelia (Ballet "Hamlet", 2010). URI :

https://www.youtube.com/watch?v=iTJS-bz9u6A\&feature=emb_logo

74. Viola tricolor. URI : https://plants.ces.ncsu.edu/plants/viola-tricolor/

75. Violets in Shakespeare. URI : https://bardgarden.blogspot.com/2014/10/violets-in- 
shakespeares-works.html

76. William

Paul

(horticulturalist)

URI:

https://en.wikipedia.org/wiki/William_Paul_(horticulturalist)

77. Reflection on "Hamlet". Film-ballet to Ballet to music D. Shostakovich based on William Shakespeare's tragedy "Hamlet"; staged by choreographer S. Voskresenskaya (1991). URI : https://www.youtube.com/watch? $\mathrm{v}=\mathrm{aJWHFrMtxB} 4$

URI : https://www.youtube.com/watch? $\mathrm{v}=\mathrm{aJWHFrMtxB} 4$

78. "Hamlet" (1990), dir. F. Zeffirelli (Great Britain, USA, France). URI: https://gidonline.io/film/gamlet-1990/

79. "Hamlet" (1964), "Lenfilm"; dir. Kozintsev. URI:

https://www.culture.ru/movies/594/gamlet

80. Lebedeva Lyudmila. $\quad$ Ophelia. $\quad$ D. William Waterhouse. URI : https://www.liveinternet.ru/users/3251944/post456313933/

81. Petko L. Competence approach in the professional development of biology students (on the example of studying roses in foreign sources). Ukrainian Polish studies. 2020. Volume 18 (20). doi: https://doi.org/10.35433/2220-4555.18.2020.ped-7

82. Kornilova Elena Nikolaevna. The symbolism of the image of Ophelia in modernist discourse and its embodiment in the poetry of early German modernism. Practices and Interpreta URL: https://cyberleninka.ru/article/n/simvolika-obraza-ofelii-v-modernistskom-diskurse-i-egovoploschenie-v-poezii-rannego-nemetskogo-ekspressionizmations: A Journal of Philological, Educational and Cultural Research. 2018. No. 2.

83. Notable Rose Hybridizers. $\quad$ Pernet-Ducher. URI : https://www.countrycareroses.org/hybridizers

\section{Translation of the Abstract to the Author's Language}

УДК 378.147:81'243]:582.639.11

Турчинова Г., Петько Л., Новак Т. Троянда "Офелія" та символізм квітів в «Гамлеті».

У статті розглядаються актуальні проблеми, пов'язані 3 якістю професійної підготовки майбутніх біологів. Стаття демонструє необхідність та об'єктивний характер трансформації мовної та освітньої парадигми від комунікативної до міжкультурної. Автори підкреслюють, що важливо в процесі навчання студентів-біологів іноземної мови створити таке професійно орієнтоване іншомовне навчальне середовище, яке формувало б професійну та соціокультурну компетентності у студентів. Автори пропонують нестандартний підхід до формування професійної компетентності у майбутніх біологів: дослідження біологічних характеристик троянди «Офелія», виведеної селекціонером Уільямом Полом, шляхом вивчення трагедії Шекспіра «Гамлет» у контексті образу Офелії - символу жіночності. Ї̈ї слова та рядки, адресовані прекрасній дівчині, розкривають нам не тільки іï характер, a i погляди Шекспіра на жіночність. Смерть Офелії набуває символічного смислу загибелі поезії, краси і чистоти в світі, повному насильства і відчаю.

Враховуючи важливість формування професійної та мовленнєвої культури, особлива увага приділяється також професійно орієнтованим технологіям у навчанні міжкультурних комунікацій. Описано символіку квітів "букета" Офелії, а також як образ Офелії представлено у мистецтві: фільмах, музиці, балеті, живописі.

Ключові слова: майбутні біологи, іноземна мова, професійна компетентність, соціокультурна коспетентність, троянда «Офелія», селекціонер троянд Уільям Пол, Шекспір, символізм квітів. 